\title{
Water extended input-output analysis of the Croatian economy ${ }^{* 1}$
}

\author{
Saša ¿̌egar ${ }^{2}$
}

\begin{abstract}
The main objective of this paper is to identify the most important direct and indirect sources of water use in the Croatian economy and, based on that, to identify the key drivers of water use in the process of Croatian national production. For this purpose, water extended input-output model was constructed and empirically applied in the paper, based on which the indicators of direct, indirect, and cumulative water intensities of production sectors in the Croatian economy have been quantified and analysed, including their cumulative and indirect water use multipliers. Using the aforementioned model, the paper also assesses and analyses domestic, net imported, and total water footprints of production sectors in the Croatian economy, as well as the relative strength of pull-and-push effects of their water use. For the purpose of model construction, the last published input-output table of the Croatian economy for 2010 and the reference data of the Croatian official water statistics were used. The results of the model indicate that direct and indirect water use flows in the Croatian economy are mostly determined by intermediate processes of generating and using the output of the power, chemical, and oil-processing sector. Through the application of the model, it has also been found that these sectors dominate in the structure of the total water footprint of the Croatian economy, whereby the Republic of Croatia, overall, achieves a surplus in the international exchange of virtual waters. Given the new findings on indirect and cumulative water use flows in the Croatian economy, the author's recommendation is that the multiplicative effects of inter-sectoral dependencies in the processes of national production on the total water use must be taken into account when conducting future activities of planning, management, and protection of Croatian water resources.
\end{abstract}

Key words: Croatian economy, extended input-output analysis, indirect water intensity, cumulative water intensity, water footprints, forward and backward linkages

JEL classification: C67, E01, E10, F18, Q25

* Received: 22-04-2020; accepted: 09-06-2020

1 This work/research has been supported by the University of Rijeka (UNIRI), project title "Pametni gradovi u funkciji razvoja nacionalnog gospodarstva" (uniri-drustv-18-255-1424)".

2 PhD, Assistant Professor, University of Rijeka, Faculty of Economics and Business, Ivana Filipovića 4, 51000, Rijeka, Croatia. Scientific affiliation: environmental economics and policy, urban economics, local and regional development. Phone: +385 51355 120. E-mail: sasa. cegar@efri.hr.ORCID:0000-0001-8666-3419. 


\section{Introduction}

Water is a source of life that has no alternative; therefore, constant availability of clean and healthy water is imposed as a conditio sine qua non of preserving the integrity and sustainability of ecosystem services, meeting basic human needs, and stability of the socio-economic development of mankind. Due to the fact that all forms of life on Earth and all human activities depend more or less on water, it is particularly important to understand the nature and complexity of the interactive relationship between water and national economies. National economies represent the basic macroeconomic framework for the research and management of the economy and the environment; it is therefore necessary to explore all phenomena that affect the dynamics and intensity of water-use flows in national economies.

When it comes to the interaction between national economies and water, it is important to point out that water is not only one of the most important fundamental elements of the existence of the biosphere, but is also used as an irreplaceable input in different production and service sectors. Given that water-intensive sectors are linked to other sectors through value-adding chains, water is integrated directly or indirectly into the production of all final goods and services. This is because the sectors forming the production systems of national economies are not self-sufficient entities; they are interconnected and conditioned in such a way that the production of each sector involves a part of the production of other sectors. Therefore, changes in the level or structure of final production in the national economy affect the flows of water use along intertwined national and international chains of its value creation.

The problem is that direct water use indicators are still predominantly used in the preparation of analytical background for the planning and management of water resources in most countries, including the Republic of Croatia. Since water policy should be an integral part of a wider framework for sustainable development management, lack of knowledge of indirect drivers of water use certainly reduces the efficiency and quality of planning and management of national water resources. In other words, without the establishment of mechanisms and activities for regular measurement and monitoring of water use flows within interaction and feedback effects between economic and production sectors, decision-makers cannot predict development scenarios or circumstances that require more sophisticated life-cycle measures to regulate the impact of growth and diversification of national economies on the consumption of water resources.

The Republic of Croatia is relatively rich in water resources, which in the context of the international community's prediction that water will become a strategic resource of the $21^{\text {st }}$ century represents enormous potential for the Croatian economy. ${ }^{3}$

$\overline{3}$ According to Aquastat, Croatia annually has $24,185.0 \mathrm{~m}^{3}$ of total renewable water resources per capita, ranking $5^{\text {th }}$ in Europe and $31^{\text {st }}$ in the world. Although the water balance of Croatia is 
This was recognised by the National Water Management Strategy (2009), which emphasises that water resources are of primary national interest to the Republic of Croatia; therefore, their protection and management policy must be defined and implemented in accordance with the highest standards of sustainable development. This implies, among other things, the achievement of complementarity between priorities for the conservation of water resources and priorities related to economic growth and development. This de facto creates a scientific and practical need to explore direct and indirect water-use flows in the Croatian economy.

When discussing the relevance of certain methodologies for assessing and analysing direct and indirect water-use flows in the national economy, two basic approaches can be identified in the literature: the bottom-up approach and the topdown approach. The bottom-up approach starts from a specific output, and then, according to the functional (i.e. process) principle, detects water-use flows related to the production and consumption of this output. For example, the best-known bottom-up approach for assessing cumulative pressures on water resources is the water footprint calculation methodology (cf. Hoekstra et al., 2011). However, bottom-up methodologies have limited capacity for comprehensive assessment and analysis of cumulative water use generated by the flows of production and consumption of goods and services in the national economy. This is because, from a bottom-up perspective, it is very difficult to systematically cover all processes that directly or indirectly support a certain production and supply chain, and thus precisely balance all the water-use flows in these processes (cf. Giljum et al., 2013, pp. 13-14).

In order to overcome this problem, the methodology of input-output analysis is most often used in scientific research practice, since it enables the application of the top-down approach in quantifying cumulative pressures on the environment and natural resources. In the context of water use, this means that the starting point are sectoral indicators of direct water use, which must then be integrated into inputoutput data of the national economy. The complex data compilation created in this way enables the application of special mathematical procedures (i.e. input-output models) for calculating direct, indirect, and cumulative water use for each sector into which the national economy is divided (cf. Chapter 3). Since water extended input-output models represent the comprehensive, yet simple tools for quantifying water-use flows along entire value chains of production and distribution, these models have a standard and very wide application in the field of research of the relationship between economy and water resources (cf. Chapter 2). This is also the main reason why the author chose this methodology for the realisation of the

characterised by a relatively high coefficient of dependence on external water resources $(76.6 \%)$, the total annual volume of water abstraction in the Republic of Croatia amounts to only $3.7 \%$ of its inland water resources. 
main objective of this paper, which is to quantify and analyse direct, indirect, and cumulative effects of production activities in the Croatian economy on water use and on that basis identify key water-intensive sectors and key drivers of water use in the Croatian economy.

\section{Literature review}

It is generally known that the methodological framework of input-output analysis provides a comprehensive and consistent basis for the determination and quantification of direct and indirect intersectoral dependencies within the production system of the national economy, but also for the consideration of its connection with foreign economies. Although some forms of analysis of intersectoral relations can be found in earlier economic literature (cf. Kurz \& Salvadori, 2000), the main initiator and creator of input-output analysis is considered to be Professor Wassily Leontief, who was awarded the Nobel Prize for Economics (cf. Leontief, 1986). Practical application of input-output analysis methodology was initially mainly limited to assessing and analysing the impact of different components of final demand on domestic production, gross value added, and employment (i.e. Mikulić et al., 2014, p. 77). However, ever since the theoretical and methodological assumptions for expanding the analytical framework of traditional input-output models with quantitative data on resource consumption and emissions to the environment have been established in the 1960s, input-output analysis has become a widely accepted empirical tool in the field of research of economic-environmental relations (cf. Cruz, 2002, p. 3). The extended inputoutput models enable quantification of direct and indirect environmental pressures generated by production sectors ${ }^{4}$ in order to meet final demand in the national economy; therefore, they provide a comprehensive analytical basis for identifying key sources and drivers of environmental pressures in the national economy (cf. Tukker et al., 2006, pp. 19-31).

The expanded or hybrid input-output analysis ${ }^{5}$ was initially most used in the research of the impact of individual economies on energy consumption and greenhouse gas emissions while, due to the lack of disaggregated data on economic pressures on water resources, it was very rarely used in the research of water issues (cf. Duarte \& Yung, 2011). However, after the UN Statistical Department published in 1993 a manual System of Integrated Environmental and Economic Accounts (SEEA) that proposed methodological guidelines for linking environmental statistics with

\footnotetext{
$\overline{4}$ In the context of input-output analysis, all sectors producing goods and providing services are called production sectors.

5 Extended input-output models that combine monetary and non-monetary data are called hybrid input-output models.
} 
the system of national accounts, statistical institutions in many countries began to use economic classifications in collecting, organising, and publishing data in the field of water statistics. ${ }^{6}$ This has provided basic preconditions for a more intensive application of input-output analysis in the research of economic pressures on water resources, which in the last 20 years contributed to the strong development of this specific scientific and research area.

Based on literature review, it can be concluded that input-output methodology can be used for analysis of different aspects of water-economy nexus. For example, Eunnyeong et al. (1999) analysed the characteristics of the intermediate linkages of the water supply sector and based on that assessed its role and importance in the economy of South Korea. Through the input-output methodology, Lenzen and Foran (2001) analysed the multiplicative effects of population growth and household consumption on water use in Australia's economy. Velazquez (2006) conducted an input-output analysis of direct and indirect water use in the economy of the Spanish province of Andalusia. Using the extended input-output analysis method Kobayashi and Oyasato (2008) estimated the total water consumption of Japan, including the quantities of water needed to produce imported goods and services. Yu et al. (2010) used the extended regional input-output model to assess domestic and net imported water footprints of economic and household sectors in South-East and North-East England. Based on the hybrid input-output model, Qin (2011) determined which sectors directly and indirectly contribute the most to water use in the economy of the Haihe River catchment area in China. Hristov et al. (2012) investigated the impact of cross-sectoral relations in the national economy on the consumption of water resources in the Republic of Macedonia. Yakovleva and Kudryavtseva (2013) used the extended input-output analysis method to assess the impact of foreign trade on total direct and indirect water demand in key industrial sectors of Russia. Di Cosmo et al. (2014) analysed key drivers of economic water use in the European Union using input-output methodology.

Although Croatian economic science has made a significant contribution to the theoretical and application development of input-output analysis (cf. Jurčić, 2000; Mikulić, 2018), to the best of the author's knowledge, by the time this paper was written, no empirical research had been published based on the application of the hybrid input-output analysis methodology on the example of the Croatian economy, whether in terms of water or any other natural resource or environmental components.

\footnotetext{
6 The SEEA framework has so far been revised several times and upgraded by various subsystems that are specially developed for accounting and monitoring of specific areas. In 2012, the System of Environmental-Economic Accounts for Water (SEEA-Water) was published as the first international standard for integrated water accounting. The current development of integrated water accounting at the global level has been elaborated in detail in Jian, Song \& Li (2016).
} 


\section{Methodology}

The water extended input-output model of the Croatian economy is constructed in this part of the paper, and the basic assumptions and limitations of its application and data used in the model are explained.

\subsection{Basic input-output model}

If the production system of the national economy is classified into $n$ sectors, the classical format of input-output table of the national economy may be extended with a single vector row containing data on the total annual direct water use for each of the $n$ sectors (cf. Table 1$)^{7}$

Table 1: Water extended input-output table

\begin{tabular}{|l|c|ccccc|c|c|}
\hline \multicolumn{7}{|c|}{ Output } & \multicolumn{5}{|c|}{ Intermediate use (demand) } & Final use \\
Input & Sectors & 1 & $\cdots$ & $\mathrm{j}$ & $\cdots$ & $\mathrm{n}$ & Total \\
output
\end{tabular}

Source: prepared by the author

Elements of the intermediate use matrix in Table 1 are marked $x_{i j}$, where $i$ is the sector that delivers intermediate products (i.e. output) and $j$ is the sector that uses intermediate products (i.e. input). Thus, the $x_{i j}$ mark represents a part of sector $i$ 's annual output used in the production of sector $j$. Since $X_{i}$ denotes the gross value of production of sector $i$, and $f_{i}$ denotes total final use of the production of the sector $i$, the entire national economy can be described by the following system of linear equations: ${ }^{8}$

\footnotetext{
7 The derivation and interpretation of the basic input-output model is based on: Frenger (1978, p. 274), Leontief (1986, pp. 22-27), Ten Raa (2006, pp. 14-23), Eurostat/European Commission (2008, pp. 486-489) and Miller \& Blair (2009, pp. 10-34).
}

8 Since the total flows of use of inputs must be equal to the total flows of use of outputs, $X_{j}=X_{i}$. 


$$
X_{i}=\sum_{j=1}^{n} x_{i j}+f_{i}, \text { for each } i=1,2, \ldots, \mathrm{n}
$$

The intensities of direct cross-sectoral relations, i.e. dependencies in output production, are expressed by the so-called technical production coefficients calculated as follows:

$$
a_{i j}=\frac{x_{i j}}{X_{j}}
$$

The technical coefficient $a_{i j}$ represents a part of the production of the sector $i$ used in the production of one unit of output of sector $j$. Therefore, the value of the total quantity of production inputs delivered by the sector $i$ to sector $j\left(x_{i j}\right)$ can be expressed as output function of sector $j\left(x_{i j}=a_{i j} X_{j}\right)$. If this substitution is introduced into the equation system (1), the following expression is derived:

$$
X_{i}=\sum_{j=1}^{n} a_{i j} X_{j}+f_{i}, \text { for each } i=1,2, \ldots, \mathrm{n}
$$

Assuming that $a_{i j}$ are constants, and $f_{1}, \ldots, f_{n}$ default values, the equation system (3) in fact represents a system of $n$ linear equations with $n$ unknown variables that establish direct links between outputs of all $n$ sectors. In this sense, the quantification of multiplicative (i.e. cumulative) effects of individual sector's unit production on the production of all other sectors is reduced to solving the mathematical problem of finding new values $X_{1}, \ldots, X_{n}$ arising from the change of any $f_{i}$. For this purpose, the equation system (3) can be presented in the matrix form:

$$
x=A x+f
$$

wherein:

$x$ - total output vector column $\left(X_{i}\right)$

$A$ - matrix $(n \times n)$ of technical coefficients $\left(a_{i j}\right)$

$f$ - final demand vector column $\left(f_{i}\right)$

By solving the equation (4), the basic Leontief input-output model of production is obtained showing the correlation between the total output level of each sector and the level of final demand for the output of each sector:

$$
x=(I-A)^{-1} f
$$

wherein:

$I$ - unit matrix $(n \times n)$

$(I-A)^{-1}-$ Leontief Inverse Matrix $(\mathrm{L}, n \times n)$ 
The elements of the L matrix $\left(l_{i j}\right)$ reflect the cumulative (i.e. total direct and indirect) effect of the unit change in the final demand for sector $j$ 's output on the production of the total sector $i$ 's output:

$$
l_{i j}=\frac{\partial X_{i}}{\partial f_{j}}
$$

\subsection{Water extended input-output model and water multipliers}

In the extension of the basic input-output model it is first necessary to connect water use with the production of each sector. The link between the total production flows of sector $j$ and its direct water use can be expressed quantitatively by using the direct water use coefficient $\left(d_{j}\right)$, i.e. direct water intensity of sector $j:{ }^{9}$

$$
d_{j}=\frac{w_{j}}{X_{j}}
$$

wherein:

$w_{j}-$ total direct water use of sector $j$

$X_{j}$ - value of the total inputs of sector $j$

In the input-output model, direct water use coefficients are presented in diagonal order matrix $n(\hat{d})$. By multiplying the matrix $\hat{d}$ with the L matrix, it is possible to calculate for each of the $n$ sectors how much water needs to be used in the entire economy in order to produce one unit of their output:

$$
T=\hat{d}(I-A)^{-1}
$$

Matrix T is a square matrix of order $n$ whose elements $\left(t_{i j}\right)$ measure the total direct and indirect water use of the sector $i$ which is necessary for the production of one unit of output of sector $j$.

Therefore, the sum of all elements in $j^{\text {th }}$ column of this matrix $\left(t_{j}\right)$ equals the cumulative (i.e. direct and indirect) water intensity of sector $j$. On the other hand, the sum of all elements in the $i^{\text {th }}$ row of the matrix $\left(t_{i}\right)$ equals the cumulative water use in the sector $i$ that is necessary for each of the $n$ sectors to produce one unit of their own output. Water use multipliers can be calculated as follows:

$\overline{8}$ The extract and interpretation of the water extended input-output model is based on: Velazquez (2006), Guan and Hubacek (2006), Qin (2011), and Hristov et al. (2012). 


$$
\begin{aligned}
& m_{j}=\frac{t_{j}}{d_{j}} \\
& m_{j}^{\text {ind }}=m_{j}^{d}-1
\end{aligned}
$$

The multiplier $m_{j}$ shows for how much the cumulative water use of sector $j$ will increase if its direct water use increases by $1 \mathrm{~m}^{3}$. The multiplier $m_{j}^{\text {ind }}$ shows for how much indirect water use of sector $j$ will increase if its direct water use increases by $1 \mathrm{~m}^{3}$.

Using the previously derived direct water use coefficient matrix $(\hat{d})$ and the cumulative water intensity matrix $(\mathrm{T})$, it is possible to calculate the cross-sectorial water flow matrix (W):

$$
W=T-\hat{d}
$$

The newly obtained $W$ matrix is a square matrix of row $n$, the columns of which reflect the structure of indirect water use for each of the $n$ sectors. Therefore, the sum of all elements in $j^{\text {th }}$ column of the $\mathrm{W}$ matrix $\left(w_{i j}{ }^{\text {inter }}\right)$ equals the total indirect water use of the $j$ sector per unit of its output.

The $\mathrm{W}$ matrix can be converted into a matrix of technical coefficients of cumulative water use $\mathrm{Q}\left(q_{i j}\right)$ as follows:

$$
q_{i j}=\frac{w_{i j}^{i n t e r}}{d_{j}}
$$

The technical coefficient of cumulative water use $\left(q_{i j}\right)$ is the measure of cumulative water use of the sector $i$ related to $1 \mathrm{~m}^{3}$ of direct water use of sector $j$. Therefore, the sum of elements in the $j^{\text {th }}$ column of the Q matrix is equal to the value of the indirect water use multiplier of sector $j$ (cf. equation 10).

\subsection{Input-output model of water footprint}

The water footprint concept is broader than the previously derived indicators of direct, indirect, and cumulative water use because it also takes into account international virtual water flows in foreign trade (cf. Hoekstra \& Hung, 2002; Hoekstra \& Chapagain, 2008; Guan \& Hubacek, 2006). Imports of virtual waters represent indirect domestic use of foreign water resources; therefore, it contributes to the water footprint of the importing country. By contrast, virtual water exports constitute indirect foreign use of domestic water resources; they therefore do not enter into the calculation of the water footprint of the exporting country. Thus, the total water footprint of the national economy is equal to the sum of the total water 
use in that economy (i.e. domestic water footprint) and net imported virtual waters (i.e. net imported water footprint).

Since the input-output analysis methodology of the national economy enables, among other things, quantification of direct and indirect effects of foreign trade, by using the water extended input-output model it is possible to calculate domestic, net imported, and total water footprints for all $n$ sectors.

Domestic water footprint (DWF) is the total quantity of water used by domestic producers in the production of national output reduced by the amount of water used to produce the exported output:

$$
D W F=\hat{d}_{1}(I-A)^{-1} \hat{f}_{\text {dom }}
$$

wherein:

$\hat{d}_{1}-$ diagonal matrix of direct water use coefficients

$(I-A)^{-1}-$ Leontief Inverse Matrix

$\hat{f}_{\text {dom }}-$ diagonal matrix of domestic demand ${ }^{10}$

When calculating imported water footprints, it is assumed that the direct and indirect intensity of water use in the production of imported goods and services is the same as in domestic production (cf. Renault, 2002). Although this is an unrealistic assumption, because different countries have a different technological production base, the imported water footprints calculated in this way clearly indicate to what extent would national water resources be additionally burdened if a share of imports was substituted by domestic production. Taking into account this assumption, net imported water footprints (NIWF) are calculated as follows:

$$
N I W F=\hat{d}_{1}(I-A)^{-1}(\hat{x}-\hat{m})
$$

wherein $\hat{x}$ and $\hat{m}$ are diagonal matrices of exports and imports.

Finally, the sum of the domestic and net imported water footprint provides an indicator of the total water footprint (TWF):

$$
T W F=D W F+N I W F
$$

$\overline{{ }^{10} \text { Domestic demand }}$ is obtained by deducting the value of exports from the value of final demand (cf. Annex 1). 


\subsection{Pull and Push water use indices}

Pull and Push indices measure the relative strength of backward and forward linkages of production sectors in the national economy. In the context of water use, backward linkage implies the effect of changing the final demand for output of sector $j$ on water use in sectors that directly or indirectly meet its needs for production inputs. By contrast, the forward linkage implies the sensitivity of water use in the sector $i$ to the change of the final demand for output of sectors that directly or indirectly use the output of the $i$ sector (i.e. Yu et al., 2010, p. 1143).

The absolute strength of the backward linkage of sector $j\left(B_{j}\right)$ is calculated as the sum of elements in $j^{\text {th }}$ column of the cumulative water use coefficient matrix (T) (cf. equation 8):

$$
B_{j}=\sum_{i=1}^{n} t_{i j}
$$

The absolute strength of forward linkage is calculated using an alternative inputoutput model, which, according to its author, is called the Ghosh input-output model. Unlike the original Leontief model (cf. equation 5), the Ghosh model connects total output $(X)$ and primary inputs $(p)$ as shown below (cf. Davar, 2005; Maresa \& Sancho, 2012):

$$
x=(I-B)^{-1} p
$$

wherein:

B - matrix $(n \times n)$ of the technical allocation coefficients $\left(b_{i j}=x_{i j} / X_{i}\right)$

$(I-B)^{-1}-$ Ghosh Inverse Matrix $(\mathrm{G}, n \times n)$

The elements of the $\mathrm{G}\left(g_{i j}\right)$ matrix reflect the overall effect of the unit change of the sector $i$ 's primary inputs on the total output of sector $j$. Therefore, the absolute strength of the forward linkage of sector $i$ in terms of water use $\left(F_{i}\right)$ can be calculated as the sum of elements in the $i^{\text {th }}$ row of the cumulative water supply coefficient matrix $(V)$ obtained by multiplying the Ghosh Inverse Matrix by the diagonal matrix of direct water use coefficients $(\hat{d})$ :

$$
\begin{aligned}
& \mathrm{V}=\hat{d}(I-B)^{-1} \\
& F_{i}=\sum_{j=1}^{n} v_{i j}
\end{aligned}
$$

Previously defined absolute strengths of backward and forward linkages of production sectors can be relatively expressed in the form of Pull and Push water 
use indices (cf. Duarte \& Sánchez-Chóliz, 1998; Alonso, 2004; Yu et al., 2010; Qin, 2011; Bekchanov, et al., 2014): ${ }^{11}$

$$
\begin{gathered}
P L I_{j}=\frac{B_{j}}{\frac{1}{n} \sum_{j=1}^{n} B_{j}} \\
P S I_{i}=\frac{F_{i}}{\frac{1}{n} \sum_{i=1}^{n} F_{i}}
\end{gathered}
$$

If the value of the Pull index $\left(P L I_{j}\right)$ of sector $j$ is greater than 1 , the unit increase of the final demand for the production of sector $j$ will result in an above-average increase in water use in all sectors of the national economy. On the other hand, if the value of the Push index $\left(P S I_{i}\right)$ of the sector $i$ is greater than 1, the unit increase in the final demand for production of all sectors in the national economy will result in an above-average increase in water use in sector $i$.

\subsection{Basic assumptions and limitations of the model}

The designed water extended input-output model is a version of the so-called open static input-output model which is based on the following assumptions (i.e. Gretton, 2013, p. 4; Gupta, 2009, pp. 635-637):

1. All enterprises within a particular sector use the same technology and produce identical products, which implies full homogeneity of sectoral production.

2. All production inputs are perfect complements in the production process; therefore, there is no possibility of their substitution, i.e. all sectors have a fixed structure of production inputs and achieve constant yield on production volume.

3. All sectors have absolute adequacy of production capacities, which is why any increase in final demand is accompanied by a proportionate increase in national production.

Since these assumptions do not reflect the real economic reality, the following limitations in the application of this model can be recognised (i.e. OECD, 1992; Jain \& Ohri, 2007, p. 234; NWT Bureau of Statistics, 2006, p. 8):

\footnotetext{
${ }^{11}$ In the literature there are several approaches for measuring the relative strength of backward and forward linkages in the production system of the national economy. Indices defined by Rasmussen (1956), which are often used in literature, were used for research purposes in this paper. These indices measure the deviation of absolute strength of backward and forward linkages in relation to their average value.
} 
1. Diversification of production assortment and production inputs is one of the basic business strategies for adjustment of companies to constantly changing market conditions; therefore, the assumption of complete homogeneity of sectoral production has no basis in economic reality.

2. The assumption that production factors are constantly available (i.e. sufficiency of production capacities) does not take into account the problem of collective competition over production factors. Therefore, in reality, certain sectors cannot significantly increase their production without taking over part of the resources needed to increase the production of other sectors.

3. Due to the assumption of constant return to scale, the model does not take into account the impact of the existence of economies and diseconomies of scale in different sectors on their demand for intermediate goods and thus on the multiplicative effects of their production on other sectors.

4. The assumption of the fixed structure of inputs and the inability to substitute them ignores the fact that growth or fall in demand for production inputs actually leads to a change in relative input prices, which can lead to the substitution of inputs in production and consequently to a change in intermediary relationships in the production system of the national economy. There are also numerous factors that can affect the productivity and efficiency of enterprises (e.g. knowledge, technology) and thus reduce or increase the degree of their dependence on certain intermediate inputs.

5. In practice, there is a significant interval of time between the collection of data necessary for the creation of input-output tables and their publishing, which brings into question the accuracy of technical production coefficients.

It is important to point out that all these limitations almost exclusively relate to the accuracy and reliability of open static input-output models as simulation and prognostic tools. On the other hand, their capacities and capabilities in the analysis of production systems and economic structures are still unique and even irreplaceable compared to other analytical tools and methodologies. The reason is that the A matrix (cf. equation 2) credibly reflects the technical structure of the production system of the national economy in a specific period of time and at a precisely defined level of its aggregate economic activity, which enables the practical application of the theory of overall interdependence in the empirical analysis of direct and indirect links between different parts of national economies as complex systems (i.e. Gerking, 1976, p. 2). Also, although the technical production coefficients in each national economy vary over time, they do not change so rapidly (cf. Sun \& Wong, 2014; Hermannsson, 2010). Therefore, open static input-output models can be useful both as simulation and prognostic tools, but not in terms of precise quantification of multiplicative changes in the production system of the 
national economy that can be caused by certain endogenous or exogenous factors, but in terms of determining the direction and general extent of these changes. Therefore, the application of a static input-output analysis can certainly contribute to a better understanding of the impact of cross-sectoral dependencies on water use in the national economy, but also on other forms of economic pressures on natural resources and the environment.

However, there is an obvious empirical constraint on extended input-output models in quantification and analysis of indirect and cumulative flows of natural resource consumption and emissions into the environment, which is not pointed out in the literature. As a rule, data in satellite accounts of natural resources and the environment are presented according to standard classifications of economic activities based on the principle of main activity. On the other hand, data in inputoutput tables are obtained by transforming supply and use tables from activity - product form to product - product form. This implies a complex process of linking and reducing data expressed according to the classification of activities and data presented by product classification into a single sector classification based on the principle of homogeneous manufacturing sector (cf. Eurostat, 2008, pp. 295-297). The problem is that most companies in a certain country do not only carry out the main activity for which they are registered, but part of their total output includes goods and services which, according to the criteria of original economic origin, imply the pursuit of some other activities (i.e. secondary goods and services). Therefore, data on, for example, the total water use in individual economic activities are not fully equivalent to the total water use in similar homogeneous production sectors. ${ }^{12}$ Therefore, in order to reliably and correctly interpret the results obtained by extended input-output models, the author recommends previous verification of the structure of output values by product types in the supply-use tables for each economic activity. If typical products are predominant in the total output of each economic activity, extended input-output models may produce high-quality and reliable results. However, if there is a significant share of secondary products in the total output of certain activities, it is necessary to interpret the results obtained with caution, especially if they are water-intensive secondary products.

\subsection{Data sources}

A symmetric input-output table of the Croatian economy for 2010, published in $65 \times 65$ format (CBS, 2015), was used in the construction of water extended inputoutput model of the Croatian economy. Since the available data on the economic

\footnotetext{
$\overline{12}$ Therefore, it is necessary to develop statistical standards for the regular monitoring of environmental pressures and natural resources, which, in addition to the current economic classifications of activities, are based on the applicable economic classifications of products.
} 
use of water are not organised according to the same level of aggregation (i.e. of detail) as input-output data, the original version of the input-output table is reduced to $24 \times 24$ format. For the purpose of this research, the production system of the Croatian economy was classified into 24 sectors (cf. Table 2).

Table 2: Classification of Production Sectors

\begin{tabular}{|c|c|c|c|}
\hline Labels & Production sectors & Labels & Production sectors \\
\hline 1 & Primary sector & 13 & Metallic sector \\
\hline 2 & Mining and quarrying & 14 & $\begin{array}{l}\text { Manufacture of computer, electronic } \\
\text { and optical products and electrical } \\
\text { equipment }\end{array}$ \\
\hline 3 & Food sector $^{12}$ & 15 & $\begin{array}{l}\text { Manufacture of machinery and } \\
\text { equipment }\end{array}$ \\
\hline 4 & Textile sector ${ }^{13}$ & 16 & $\begin{array}{l}\text { Manufacture of motor vehicles, } \\
\text { trailers, semi-trailers and their transport } \\
\text { equipment }\end{array}$ \\
\hline 5 & Wood-processing sector ${ }^{14}$ & 17 & $\begin{array}{l}\text { Manufacturing of furniture and other } \\
\text { manufacturing }\end{array}$ \\
\hline 6 & $\begin{array}{l}\text { Manufacture of paper and paper } \\
\text { products }\end{array}$ & 18 & $\begin{array}{l}\text { Repair and installation of machinery and } \\
\text { equipment }\end{array}$ \\
\hline 7 & $\begin{array}{l}\text { Printing and production of recorded } \\
\text { media }\end{array}$ & 19 & Power sector ${ }^{15}$ \\
\hline 8 & Oil-processing sector ${ }^{16}$ & 20 & Water collection, treatment and supply \\
\hline 9 & Chemical sector & 21 & $\begin{array}{l}\text { Waste management and environmental } \\
\text { remediation }\end{array}$ \\
\hline 10 & Pharmaceutical sector & 22 & Construction \\
\hline 11 & $\begin{array}{l}\text { Manufacture of rubber and plastic } \\
\text { products }\end{array}$ & 23 & Hospitality sector \\
\hline 12 & Non-metallic sector & 24 & Other services \\
\hline
\end{tabular}

Source: Author's calculation

The newly formed input-output table has been extended along the vertical axis by adding one row which, in accordance with the classification of production sectors in Table 1, contains structured data on direct water use (cf. Annex 1). Data on direct water use in industrial sectors are taken over from the Statistical Report of

\footnotetext{
${ }^{13}$ It also includes manufacture of beverages and tobacco products.

${ }^{14}$ It also includes manufacture of wearing apparel and leather products.

${ }^{15}$ Manufacture of wood and products of wood and cork, except furniture, including manufacture of articles of straw and plaiting materials.

${ }^{16}$ Electricity, gas, steam and air conditioning supply.

${ }^{17}$ It also includes manufacture of coke.
} 
the CBS for 2010 (CBS, 2011). ${ }^{18}$ For the purpose of determining the direct water use in particular sectors as accurately as possible, part of the water statistics data had to be previously additionally processed or assessed. This primarily relates to the power sector. The reason is that most of the water used in the power sector is only passing through hydroelectric power plants, which means that the water can be used downstream again in other sectors. Therefore, in order to avoid the error of multiple calculation of directly consumed water, only quantities of water related to production, water used for cooling the plant and water used for sanitary and other purposes were taken into account in the power sector. Water intended for fish farming has a similar feature; therefore, this form of economic use of water is excluded from the assessment of the total annual water use in the primary sector. Water use in the primary sector was estimated based on data on the use of irrigation water (cf. Voća et al., 2014, p. 160) and data on quantities of water delivered in 2010 to agriculture, forestry, and fisheries from the public water supply system. ${ }^{19}$ When estimating water use in the service part of the economy, only the catering sector is singled out in particular, since it is traditionally highlighted as a significant water consumer. Water use in this sector is estimated on the basis of the water use coefficient in tourist activities (cf. Voća et al., 2014, p. 92) and data submitted by the CBS on the total delivered quantities of water from the public water supply system in 2010. Assuming that the nature of service activities operations is such that they predominantly satisfy their water needs through the public water supply system, all remaining commercial and service activities in the input-output table of the Croatian economy are aggregated into a single sector of other service activities. The estimate of the total direct water use in the sector of other service activities was also made on the basis of data on the total delivered quantities of water from the public water supply system in 2010 provided by CBS.

\section{Empirical data and analysis}

In accordance with the methodology framework presented above, this part of the paper presents the results of input-output analysis of water use in the Croatian economy.

\footnotetext{
${ }^{18}$ Since the input-output table referrs to 2010 , for the sake of credibility of analysis and interpretation of calculated indicators, the official water statistics data for 2010 were used in the model.

${ }^{19}$ Data submitted by the CBS.
} 
Saša Čegar $・$ Water extended input-output analysis of the Croatian economy

\subsection{Characteristics of direct and indirect water use in the Croatian economy}

The following table shows calculations of indicators of direct water use, indicators of direct, indirect, and cumulative water intensity and cumulative and indirect water use multipliers in the Croatian economy.

Table 3: Indicators of direct, indirect, and cumulative water use in the economy of the Republic of Croatia in 2010

\begin{tabular}{|r|r|r|r|r|r|r|}
\hline $\begin{array}{c}\text { Sector } \\
\text { labels }\end{array}$ & $\begin{array}{c}\text { Direct water } \\
\text { use }\left(\mathrm{m}^{3}\right)\end{array}$ & $\begin{array}{c}\text { Direct water } \\
\text { intensity } \\
\left(\mathrm{m}^{3} / \mathrm{mil} . \mathrm{HRK}\right)\end{array}$ & $\begin{array}{c}\text { Indirect water } \\
\text { intensity } \\
\left(\mathrm{m}^{3} / \mathrm{mil} . \mathrm{HRK}\right)\end{array}$ & $\begin{array}{c}\text { Cumulative } \\
\text { water intensity } \\
\left(\mathrm{m}^{3} / \mathrm{mil} \text { HRK }\right)\end{array}$ & $\begin{array}{c}\text { Cumulative } \\
\text { water } \\
\text { multiplier }\end{array}$ & $\begin{array}{c}\text { Indirect } \\
\text { water } \\
\text { multiplier }\end{array}$ \\
\hline 1 & $12,671,000.0$ & 459.37 & $1,192.67$ & $1,652.04$ & 3.60 & 2.60 \\
\hline 2 & $2,303,000.0$ & 114.09 & 134.93 & 249.02 & 2.18 & 1.18 \\
\hline 3 & $31,049,000.0$ & 748.09 & 922.72 & $1,670.81$ & 2.23 & 1.23 \\
\hline 4 & $3,645,000.0$ & 267.20 & 754.47 & $1,021.66$ & 3.82 & 2.82 \\
\hline 5 & $484,000.0$ & 128.26 & 683.75 & 812.01 & 6.33 & 5.33 \\
\hline 6 & $4,603,000.0$ & 740.94 & 645.54 & $1,386.48$ & 1.87 & 0.87 \\
\hline 7 & $103,000.0$ & 30.75 & $1,268.68$ & $1,299.43$ & 42.26 & 41.26 \\
\hline 8 & $143,794,000.0$ & $7,431.70$ & 304.97 & $7,736.67$ & 1.04 & 0.04 \\
\hline 9 & $92,258,000.0$ & $5,826.37$ & $1,216.29$ & $7,042.66$ & 1.21 & 0.21 \\
\hline 10 & $645,000.0$ & 80.81 & 420.69 & 501.50 & 6.21 & 5.21 \\
\hline 11 & $107,000.0$ & 15.73 & 542.41 & 558.14 & 35.48 & 34.48 \\
\hline 12 & $10,169,000.0$ & $1,398.87$ & 897.20 & $2,296.07$ & 1.64 & 0.64 \\
\hline 13 & $1,913,000.0$ & 106.02 & 287.95 & 393.96 & 3.72 & 2.72 \\
\hline 14 & $1,798,000.0$ & 88.97 & 260.63 & 349.60 & 3.93 & 2.93 \\
\hline 15 & $166,000.0$ & 14.63 & 149.86 & 164.49 & 11.24 & 10.24 \\
\hline 16 & $1,120,000.0$ & 69.86 & 240.29 & 310.15 & 4.44 & 3.44 \\
\hline 17 & $332,000.0$ & 47.26 & 406.88 & 454.15 & 9.61 & 8.61 \\
\hline 18 & $73,000.0$ & 8.74 & $1,177.97$ & $1,186.71$ & 135.78 & 134.78 \\
\hline 19 & $133,412,000.0$ & $9,784.74$ & $2,487.81$ & $12,272.56$ & 1.25 & 0.25 \\
\hline 20 & $1,621,000.0$ & 523.89 & 832.32 & $1,356.20$ & 2.59 & 1.59 \\
\hline 21 & $154,000.0$ & 26.45 & $1,293.06$ & $1,319.51$ & 49.88 & 48.88 \\
\hline 22 & $1,948,000.0$ & 40.21 & 812.77 & 852.97 & 21.21 & 20.21 \\
\hline 23 & $15,412,000.0$ & 475.02 & 886.71 & $1,361.73$ & 2.87 & 1.87 \\
\hline 24 & $35,012,000.0$ & 108.14 & 641.49 & 749.63 & 6.93 & 5.93 \\
\hline & & & & & & \\
\hline
\end{tabular}

Source: Author's calculation

According to data in Table 3, in 2010 a total of 494.8 million $\mathrm{m}^{3}$ of water was used in the Croatian economy. In absolute terms, the most important direct water users were the oil-processing sector (with 29,06\% share), the chemical sector (with $18.65 \%$ share), and the power sector (with 26.96\% share). Also, significant direct water use was achieved by the food sector (with a share of $6.28 \%$ ), and nonmetallic sector (with a share of $2.06 \%$ ). In the service part of the Croatian economy, 
the largest direct water use was recorded in the sector of other service activities (with a share of $7.08 \%$ ) and the catering sector (with a share of $3.11 \%$ ). ${ }^{20}$ On the other hand, the primary sector achieved only $2.56 \%$ of the total direct water use. ${ }^{21}$

Based on relativization of direct water use according to the realised value of annual output, it has been found that the most important direct water users also have significantly greater direct water intensity compared to other sectors. Thus, the highest direct water use per unit of output produced was recorded in the power sector, which consumed 9,784,74 $\mathrm{m}^{3}$ of water per million HRK of realised annual output (hereinafter referred to as: output unit). It is followed by the oil-processing sector (7.431.70 $\mathrm{m}^{3} / \mathrm{mil}$. HRK), and the chemical sector $\left(5.826,37 \mathrm{~m}^{3} / \mathrm{mil}\right.$. HRK). Therefore, the chemical, oil-processing, and power sector, apart from their absolute dependence, also have the highest relative dependence on water as a production input. Considering the achieved level of direct water intensity, all other production sectors are below the level of $1000 \mathrm{~m}^{3} / \mathrm{mil}$. HRK (cf. Table 3). The exception is only the non-metallic sector which in 2010 directly consumed $1398.87 \mathrm{~m}^{3}$ of water per unit of output produced.

Figure 1: Sectors with the highest direct water intensity (2010, in $\mathrm{m}^{3} / \mathrm{mil}$. HRK)

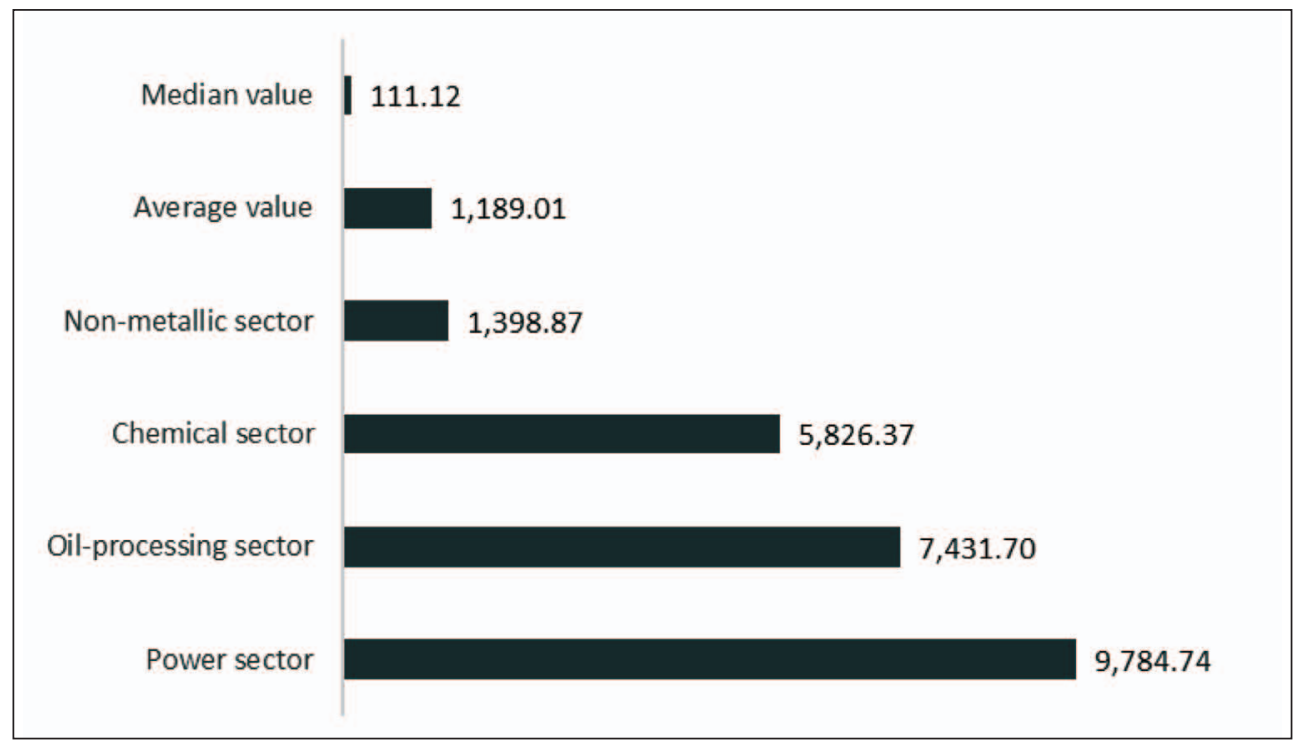

Source: Author's calculations

${ }^{20}$ Since the catering sector achieves almost half of the direct water use of all other service activities, it represents the most important direct water user in the service part of the Croatian economy.

${ }^{21}$ The main reason for this is that agricultural production in the Republic of Croatia is predominantly based on the use of rainfall water, not large systems for irrigation of agricultural areas. 
In the service part of the Croatian economy, the sector of other service activities recorded below-average direct water intensity of $108,14 \mathrm{~m}^{3} / \mathrm{mil}$. HRK, while the catering sector, as the most important direct water user in the service sector, consumed $475.02 \mathrm{~m}^{3}$ of water per output unit. A similar level of direct water use per output unit was also recorded in the primary sector $\left(459.37 \mathrm{~m}^{3} / \mathrm{mil}\right.$. HRK) (cf. Table 3).

According to the values of cumulative water intensity indicators (cf. Table 3), the power, oil-processing, and chemical sector are the most significant cumulative water users in the Croatian economy. The intensity of cumulative water use in these industrial sectors amounts to $12.272 .56 \mathrm{in} \mathrm{m}^{3} / \mathrm{mil}$. HRK, $7.736 .67 \mathrm{in} \mathrm{m}^{3} / \mathrm{mil}$. HRK, and 7.042.66 in $\mathrm{m}^{3} / \mathrm{mil}$. HRK, respectively. Why these values are so high in relation to other sectors can be best explained by the performance of the non-metallic sector, which, despite taking a high fourth position in cumulative water intensity, has as much as $67.4 \%$ lower value of this indicator than the chemical sector. Still, the cumulative water intensity of all four sectors is dominantly determined by their direct water use (cf. Figure 2).

Figure 2: Structure of cumulative water intensity of the most important direct water consumers $\left(2010\right.$, in $\mathrm{m}^{3} / \mathrm{mil}$. HRK)

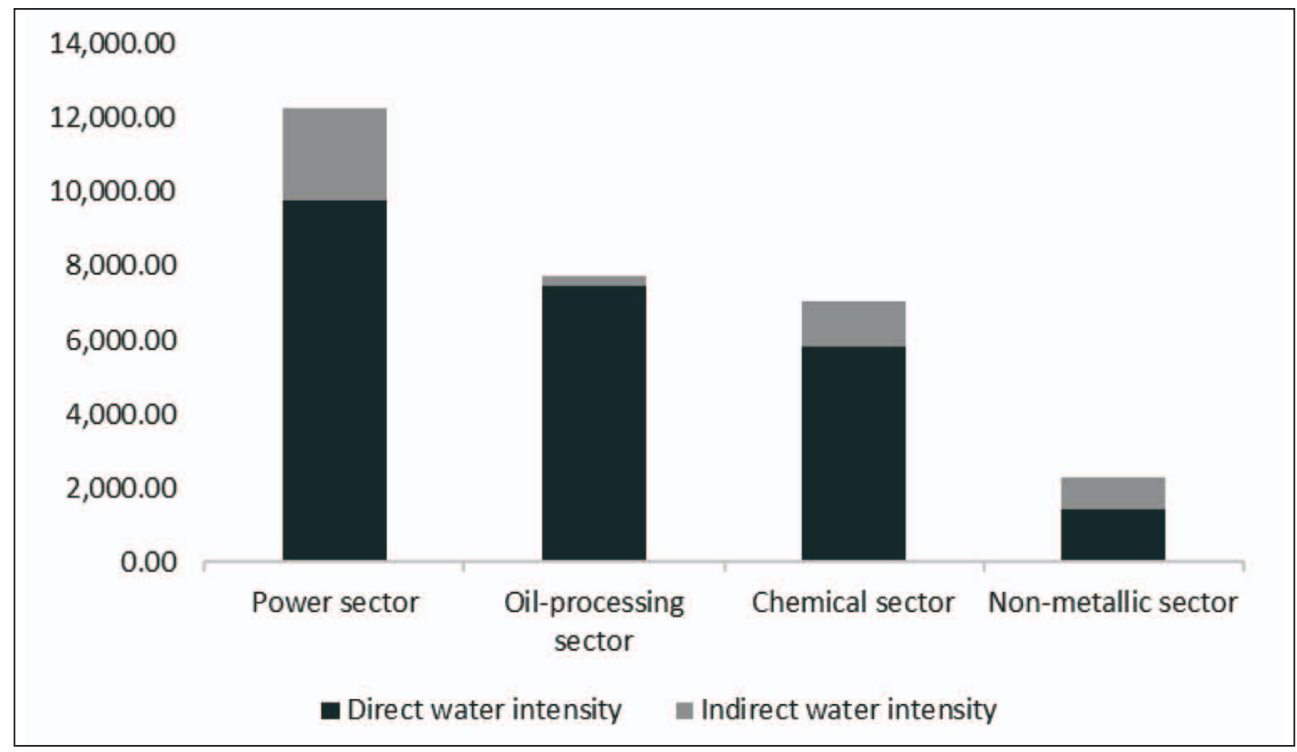

Source: Author's calculations

The data illustrated in the previous Figure 2 show that all the most important direct water users in the Croatian economy have relatively low indirect water use. ${ }^{22}$ This

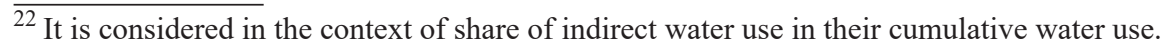


means that the Croatian economy needs considerably less amount of water to produce intermediate inputs consumed per output unit in the power, oil-processing, and chemical sector than the amount of water those sectors need to produce their own output unit. This is also confirmed by the multipliers of sectoral water use, the values of which result in the following relations (cf. Table 3):

- the power sector for each $1 \mathrm{~m}^{3}$ of directly consumed water indirectly consumes $0.25 \mathrm{~m}^{3}$ of water,

- the oil-processing sector for each $1 \mathrm{~m}^{3}$ of directly consumed water indirectly consumes $0.04 \mathrm{~m}^{3}$ of water,

- the chemical sector for each $1 \mathrm{~m}^{3}$ indirectly consumes $0.21 \mathrm{~m}^{3}$ of water.

Since the power, oil-processing, and chemical sector account for as much as three quarters of the total direct water use in the Croatian economy (cf. Table 3), it is apparent from the structure of their cumulative water intensity that the sectors recording the highest values of indirect water intensity indicators and indirect water use multipliers are in fact the main drivers of water use in the Croatian economy (cf. Figure 3).

Figure 3: Sectors with the highest indirect water intensity (2010, in $\mathrm{m}^{3} / \mathrm{mil}$. HRK)

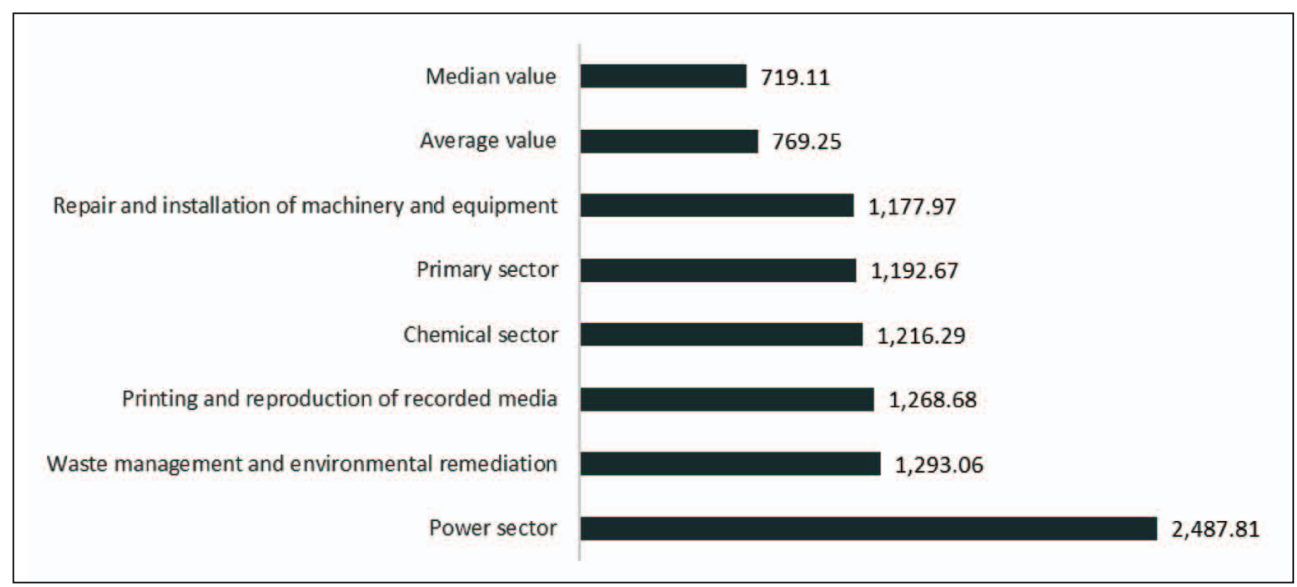

Source: Author's calculations

Although the power sector has a relatively small share of indirect water use in its cumulative water use per output unit (cf. Figure 2), this sector is, in absolute terms, still the largest indirect water consumer $\left(2,487.81 \mathrm{~m}^{3} / \mathrm{mil}\right.$. HRK). This is because approximately $50 \%$ of the value of its intermediary consumption is realised through the use of its own production and the use of the production of the oil- 
processing sector, which are in itself the largest direct water consumers (cf. Annex 1). Because of that, $95.58 \%$ of indirect water use of the power sector was caused by the use of own products and products of the oil-processing sector (cf. Annex 2). The same applies to the chemical sector where transactions between its internal activities are responsible for as much as $67.56 \%$ of its indirect water use (cf. Annex 1, Annex 2). Since a significant share of indirect water use per output unit in the mentioned sectors is de facto related to "internal water use", the results of indirect water intensity only further demonstrate the existence of high direct dependence of these sectors on water as a production input. ${ }^{23}$ In this context, it can be concluded that the sectors waste management and environmental remediation, printing and reproduction of recorded media, and repair and installation of machinery and equipment have high indirect water intensity, which in turn amounts to 1,293.06 $\mathrm{m}^{3} / \mathrm{mil}$. HRK, $1,269.68 \mathrm{~m}^{3} / \mathrm{mil}$. HRK and $1,178.97 \mathrm{~m}^{3} / \mathrm{mil}$. HRK. This means that water-intensive sectors participating in their production chain must consume significant amounts of water to meet their intermediate demand.

It is particularly important to decompose and consider the intensity of indirect water use of the primary sector $\left(1,192.67 \mathrm{~m}^{3} / \mathrm{mil}\right.$. HRK). According to the data presented in Annex 2, except for the chemical sector, the oil-processing sector, and the power sector, the use of own production and the food sector have a significant share in the structure of the total indirect water use of the primary sector per output unit. Also, there is a visible and pronounced link between the primary sector and the food sector in terms of cross-sectoral transfers of virtual water, where, naturally, the primary sector also has a significant share in indirect water intensity of the food sector. This indicates that the production and supply chain of agricultural production in the Republic of Croatia is directly related to the exploitation of national water resources, which implies that the growth of agricultural production through increased irrigation could have significant multiplicative effects on indirect and direct water use flows.

Finally, it is important to understand that the sectors that have a relatively higher share of indirect water use in their cumulative water intensity also have potentially greater power to trigger economic water use, irrespective of their current level of direct and indirect water use compared to other sectors (cf. Figure 4).

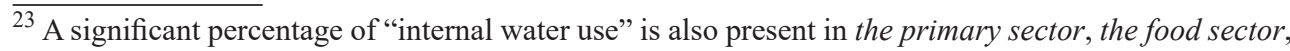
and the non-metallic sector (cf. Annex 2).
} 
Figure 4: Structure of cumulative water intensity in selected sectors $\left(2010\right.$, in $^{3} /$ mil. HRK)

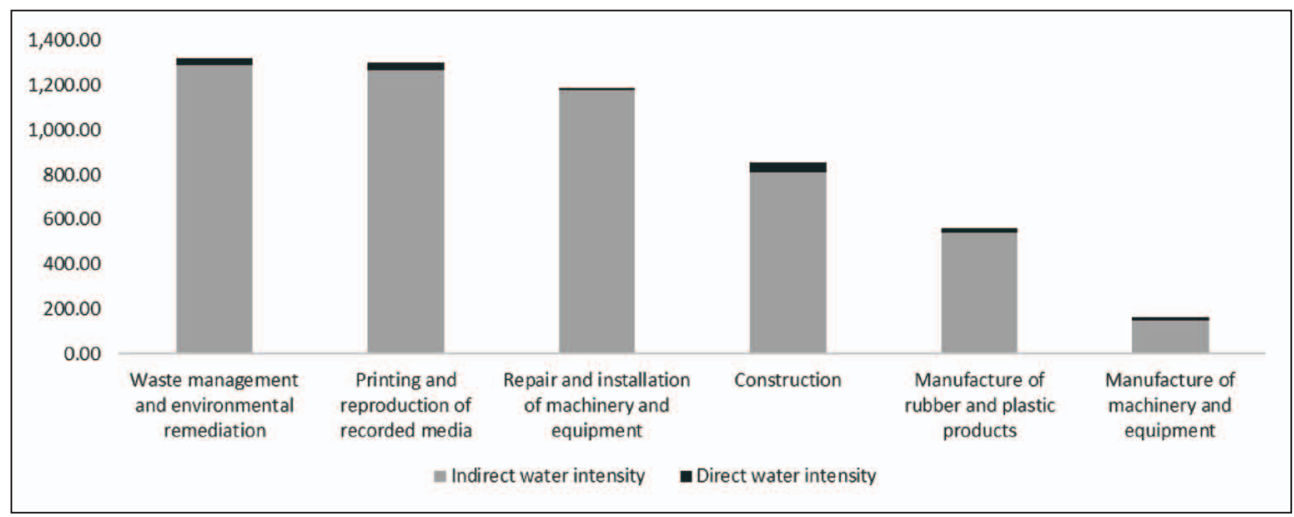

Source: Author's calculations

The proportion in which the sudden expansion of the production of sectors shown in Figure 4 may influence the rise in aggregate water demand is best reflected in the values of their water use multipliers, according to which, for each $1 \mathrm{~m}^{3}$ of water used directly (cf. Table 3):

- the repair and installation of machinery and equipment sector indirectly consumes $134.78 \mathrm{~m}^{3}$ of water,

- the waste management and environmental remediation sector indirectly consumes $48.88 \mathrm{~m}^{3}$ of water,

- the printing and reproduction of recorded media sector indirectly consumes $41.26 \mathrm{~m}^{3}$ of water,

- the manufacture of rubber and plastic products sector indirectly consumes 34.48 $\mathrm{m}^{3}$ of water,

- the construction sector indirectly consumes $20.21 \mathrm{~m}^{3}$ of water; and

- the manufacture of machinery and equipment sector indirectly consumes 10.24 $\mathrm{m}^{3}$ of water.

For example, if the value of indirect water use multiplier for the repair and installation of machinery and equipment sector is decomposed and interpreted from the aspect of water use in sectors supplying it with inputs, then it can be concluded that for each $1 \mathrm{~m}^{3}$ of water used directly in the repair and installation of machinery and equipment sector:

- the oil- processing sector must additionally consume $66.72 \mathrm{~m}^{3}$ of water,

- the power sector must additionally consume $48.82 \mathrm{~m}^{3}$ of water, 
- the chemical sector must additionally consume $9.85 \mathrm{~m}^{3}$ of water,

- the remaining production sectors must additionally consume $9.39 \mathrm{~m}^{3}$ of water together.

Using the reverse approach, it is possible to decompose the direct water use of each sector according to the structure of its intermediate supply. For example, for each consumed $1 \mathrm{~m}^{3}$ of water in the repair and installation of machinery and equipment sector, waste management and environmental remediation sector, and the construction sector, the oil-processing sector must additionally consume 66.72 $\mathrm{m}^{3}, 8.09 \mathrm{~m}^{3}$ and $6.10 \mathrm{~m}^{3}$ of water (cf. Annex 3).

\subsection{Analysis of water footprint indicators}

Since foreign trade is an indispensable part of the process of creating and distributing national output, the production sectors indirectly use the water resources of other countries through the consumption of imported inputs, but at the same time they use domestic water resources for their export production. Therefore, the so-called virtual water flows that are integrated in foreign trade between the Republic of Croatia and the rest of the world should also be taken into account for the overall assessment of water quantities needed to meet domestic demand. By linking estimated virtual water flows with data on direct and indirect water use, it is possible to calculate water footprints for all observed sectors in the Croatian economy (cf. Table 4).

Table 4: Water footprint of production sectors in the Croatian economy in 2010

\begin{tabular}{|c|r|r|r|}
\hline $\begin{array}{c}\text { Sector } \\
\text { labels }\end{array}$ & $\begin{array}{c}\text { Domestic water footprint } \\
\left(\mathrm{m}^{3}\right)\end{array}$ & $\begin{array}{c}\text { Net imported water } \\
\text { footprint }\left(\mathrm{m}^{3}\right)\end{array}$ & $\begin{array}{c}\text { Total water footprint } \\
\left(\mathrm{m}^{3}\right)\end{array}$ \\
\hline 1 & $10,699,024.94$ & $1,209,404.10$ & $11,908,429.04$ \\
\hline 2 & $1,669,542.34$ & $1,855,370.41$ & $3,524,912.76$ \\
\hline 3 & $26,897,222.06$ & $3,211,867.46$ & $30,109,089.52$ \\
\hline 4 & $3,016,694.13$ & $1,188,719.03$ & $4,205,413.16$ \\
\hline 5 & $157,540.73$ & $-81,758.52$ & $75,782.22$ \\
\hline 6 & $3,359,820.83$ & $1,806,558.15$ & $5,166,378.98$ \\
\hline 7 & $101,637.23$ & 971.15 & $102,608.39$ \\
\hline 8 & $87,684,841.04$ & $-3,601,090.76$ & $84,083,750.28$ \\
\hline 9 & $53,437,949.52$ & $41,106,394.74$ & $94,544,344.27$ \\
\hline 10 & $449,149.33$ & $205,748.52$ & $654,897.85$ \\
\hline 11 & $75,304.61$ & $62,402.95$ & $137,707.57$ \\
\hline 12 & $7,226,877.77$ & $990,959.20$ & $8,217,836.97$ \\
\hline 13 & $1,210,203.65$ & $912,281.48$ & $2,122,485.13$ \\
\hline
\end{tabular}


Saša Čegar • Water extended input-output analysis of the Croatian economy Zb. rad. Ekon. fak. Rij. • $2020 \cdot$ vol. $38 \cdot$ no. $1 \cdot 147-182$

\begin{tabular}{|c|r|r|r|}
\hline $\begin{array}{c}\text { Sector } \\
\text { labels }\end{array}$ & $\begin{array}{c}\text { Domestic water footprint } \\
\left(\mathrm{m}^{3}\right)\end{array}$ & $\begin{array}{c}\text { Net imported water } \\
\text { footprint }\left(\mathrm{m}^{3}\right)\end{array}$ & $\begin{array}{c}\text { Total water footprint } \\
\left(\mathrm{m}^{3}\right)\end{array}$ \\
\hline 14 & $1,245,632.06$ & $632,158.53$ & $1,877,790.59$ \\
\hline 15 & $129,357.07$ & $96,296.29$ & $225,653.36$ \\
\hline 16 & $657,405.30$ & $153,997.40$ & $811,402.70$ \\
\hline 17 & $222,035.93$ & $82,344.93$ & $304,380.86$ \\
\hline 18 & $42,816.71$ & $-13,011.09$ & $29,805.62$ \\
\hline 19 & $111,214,126.12$ & $20,710,671.98$ & $131,924,798.10$ \\
\hline 20 & $1,528,292.81$ & $-2,154.94$ & $1,526,137.87$ \\
\hline 21 & $97,244.29$ & $-38,312.70$ & $58,931.59$ \\
\hline 22 & $1,891,008.36$ & $-37,864.63$ & $1,853,143.73$ \\
\hline 23 & $15,129,551.16$ & $1,174,389.84$ & $16,303,940.99$ \\
\hline 24 & $29,284,914.81$ & $-1,647,455.41$ & $27,637,459.40$ \\
\hline Total & $357,428,192.80$ & $69,978,888.13$ & $427,407,080.93$ \\
\hline
\end{tabular}

Source: Author's calculation

According to the results of the model, the total water footprint of the Croatian economy in 2010 amounted to 427.7 million $\mathrm{m}^{3}$ of water, out of which 357.4 million $\mathrm{m}^{3}$ refers to the consumption of domestic water resources and 69.98 million $\mathrm{m}^{3}$ to the net imported quantity of virtual waters. The water footprint of imported inputs consumed in domestic production amounted to 207.3 million $\mathrm{m}^{3}$ of water, while 137.4 million $\mathrm{m}^{3}$ of water was used for exported production in the Croatian economy.

Looking at each sector individually, it can be concluded that the largest domestic

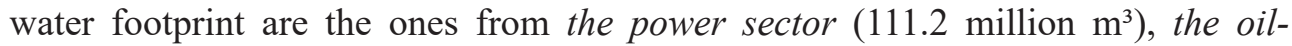
processing sector $\left(87.7\right.$ million $\left.\mathrm{m}^{3}\right)$, and the chemical sector $\left(53.4\right.$ million $\left.\mathrm{m}^{3}\right)$. They are followed by the food sector (26.9 million $\left.\mathrm{m}^{3}\right)$, the catering sector (15.1 million $\left.\mathrm{m}^{3}\right)$, the primary sector $\left(10.7\right.$ million $\left.\mathrm{m}^{3}\right)$ and non-metallic sector $(7.2$ million $\mathrm{m}^{3}$ ). All other sectors together account for only $13.3 \%$ of the total national production water footprint $\left(47.6\right.$ million $\left.\mathrm{m}^{3}\right)$. However, direct water use mostly contributes to the domestic water footprint of the power sector, the oil-processing sector, the chemical sector and the non-metallic sector, while the majority of the domestic water footprint of the food sector, the catering sector, and the primary sector refer to indirect water use (cf. Tables 3 and 4).

Assuming the equal intensity of water use in the production of domestic and foreign goods and services, Figure 5 shows the distribution of total net imported/ exported water footprint by key sectors of the Croatian economy. The sectors above the horizontal line are net importers of virtual waters, and the sectors below the horizontal line are net exporters of virtual waters. 
Figure 5: Net imported/exported water footprint per sectors in $2010\left(\mathrm{~m}^{3}\right)$

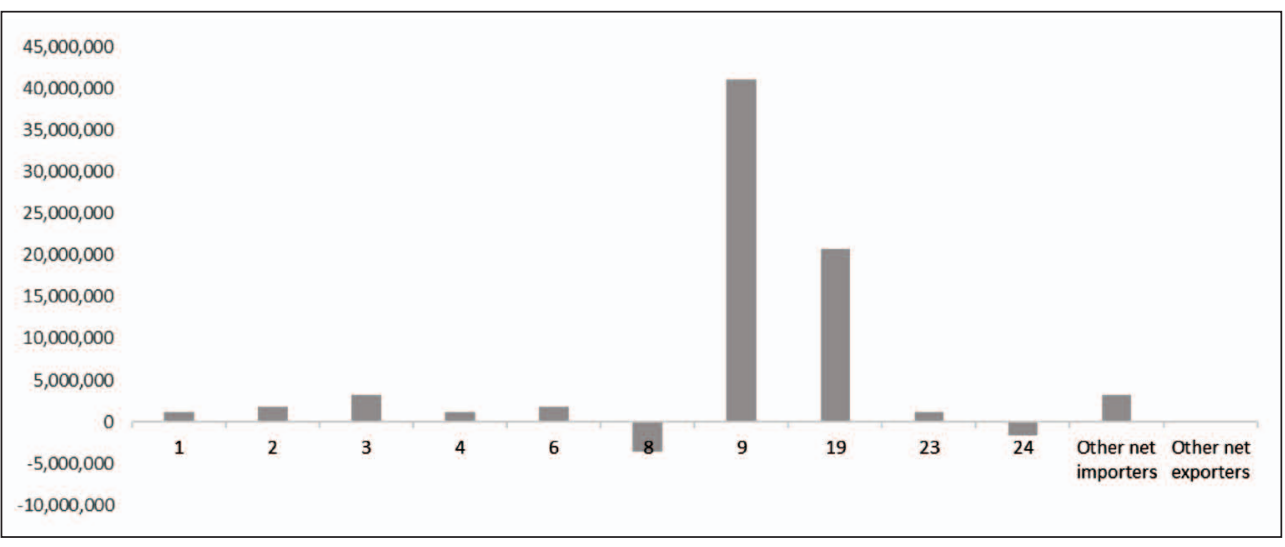

Source: Prepared by the author

According to data for 2010, the most important net importers of virtual waters are the chemical sector $\left(41.1\right.$ million $\left.\mathrm{m}^{3}\right)$ and the power sector $\left(20.7\right.$ million $\left.\mathrm{m}^{3}\right)$. The distribution of estimated net imported/exported water footprints shown above reflects the underdeveloped domestic value chains supporting the production of industrial, energy, and agricultural sectors.

Therefore, a significant part of their intermediate consumption relates to the use of imported inputs, i.e. indirect consumption of foreign water resources.$^{24}$ On the other hand, relatively small quantities of exported virtual waters can be explained by the underdevelopment of water intensive export sectors in the Croatian economy, which is why the services sector dominates the structure of total exports of the Republic of Croatia. $^{25}$

The following Figure 6 shows the structure of the total water footprint of the Croatian economy.

\footnotetext{
${ }^{23}$ In 2010, the share of imports in the total value of Croatian production amounted to $17 \%$ (cf. Annex 1).

${ }^{25}$ In 2010, the other service activities sector participated in the total exports of the Croatian economy with a share of $44.2 \%$ (cf. Annex 1).
} 
Figure 6: Structure of the total water footprint of the Croatian economy by key production sectors in 2010

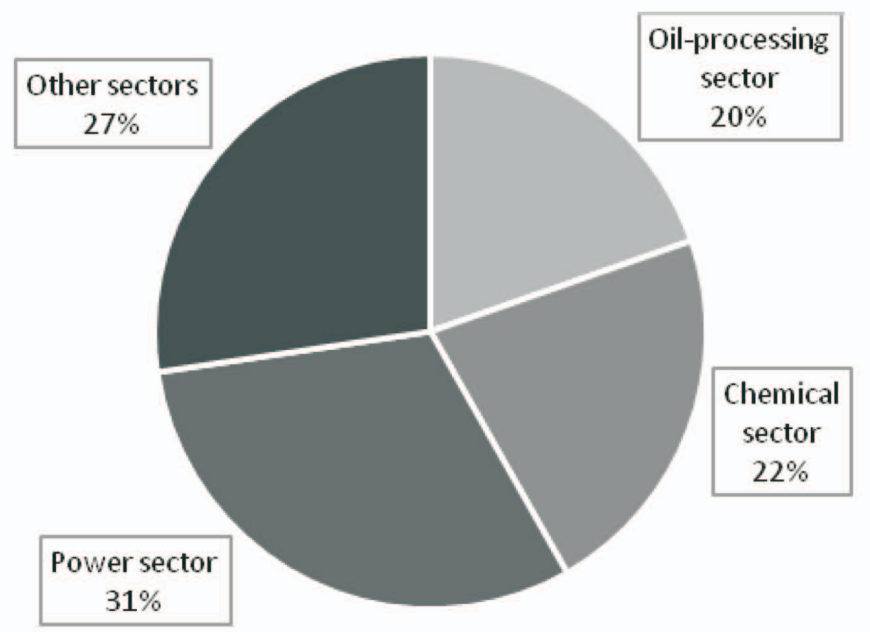

Source: Prepared by the author

According to the structure of the estimated total water footprint, it is evident that the largest water footprints are in the power sector $\left(131.9\right.$ million $\left.\mathrm{m}^{3}\right)$, the chemical sector $\left(94.5\right.$ million $\left.\mathrm{m}^{3}\right)$, and the oil-processing sector $\left(84.1\right.$ million $\left.\mathrm{m}^{3}\right)$, which together account for as much as $72.7 \%$ of the total water footprint of the Croatian economy.

\subsection{Analysis of pull and push effects of water use in the Croatian economy}

In order to gain a complete understanding of the impact of each sector on the initiating of water use flows in the Croatian economy, the relative strength of their intermediary forward and backward linkages has been analysed in this part of the paper. Accordingly, the following table shows pull and push indices of water use in the Croatian economy. 
Saša Čegar - Water extended input-output analysis of the Croatian economy

Table 5: Pull and push indices of water use in the Croatian economy in 2010

\begin{tabular}{|c|c|c|c|c|c|}
\hline Sector labels & Pull indices & Push indices & Sector labels & Pull indices & Push indices \\
\hline 1 & 0.84 & 0.50 & 13 & 0.20 & 0.29 \\
\hline 2 & 0.13 & 2.96 & 14 & 0.18 & 0.11 \\
\hline 3 & 0.85 & 0.47 & 15 & 0.08 & 0.09 \\
\hline 4 & 0.52 & 0.17 & 16 & 0.16 & 0.08 \\
\hline 5 & 0.41 & 0.23 & 17 & 0.23 & 0.10 \\
\hline 6 & 0.71 & 0.80 & 18 & 0.61 & 0.43 \\
\hline 7 & 0.66 & 0.04 & 19 & 6.27 & 6.15 \\
\hline 8 & 3.95 & 5.02 & 20 & 0.69 & 0.42 \\
\hline 9 & 3.60 & 3.85 & 21 & 0.67 & 0.27 \\
\hline 10 & 0.26 & 0.16 & 22 & 0.44 & 0.04 \\
\hline 11 & 0.29 & 0.37 & 23 & 0.70 & 0.29 \\
\hline 12 & 1.17 & 0.91 & 24 & 0.38 & 0.22 \\
\hline
\end{tabular}

Source: Author's calculation

According to the model results, the oil-processing, chemical, and power sector have the highest values of pull and push indices of water use. Since the values of both indices for these sectors are greater than 1, it can be concluded that these sectors play a key role in the overall process of water use in the Croatian economy. In other words, the unit change in the final demand for their output causes an above-average change in water use in the Croatian economy, but also a unit change in the total final demand in the Croatian economy causes an above-average change in water use in these sectors. Out of other observed sectors, only the non-metallic sector has a value of pull index greater than 1, which means that this sector has a significant strength of the backward linkage, i.e. it generates above-average total water use in the Croatian economy when purchasing and consuming intermediate inputs. On the other hand, the push index of water use exceeding 1 was also recorded in the mining and quarrying sector, indicating that this sector has above-average sensitivity of direct water use to the unit change of final demand in the Croatian economy. ${ }^{26}$

\section{Results discussion}

The results obtained by the model show that the power, oil-processing, and chemical sector are the most important sources of direct pressures on water resources in the Croatian economy. Since most of their production serves to satisfy intermediate

\footnotetext{
${ }^{26}$ Although the mining and quarrying sector has relatively small direct and indirect water use, it is excessively sensitive to the push effects of water use, because as much as $98 \%$ of its output is intended for intermediate uses (cf. Annex 1).
} 
consumption of other sectors, the final demand in the rest of the economy has strong multiplicative effects on water use in these industrial sectors. Also, these sectors also have above-average strength of forward and backward linkages in terms of water use, which is why chains of production and distribution of their output have a relatively high level of cumulative water intensity. In addition, the results of water footprint indicators indicate that intermediate needs for water intensive inputs in the Croatian economy are largely met through imports. Taking into account the natural resources - preconditions of the Republic of Croatia for the production of precisely such products, it is quite evident that there are significant potentials in the Croatian economy for substitution of a part of imports with domestic production, but also for increasing exports through stimulation of the development of waterintensive activities. This applies in particular to the power, agricultural, and food sector activities. However, summing up new findings on the nature of direct and indirect water use flows in the Croatian economy, it is realistic to expect that the increase in production in these sectors will significantly affect the overall water use in the Republic of Croatia. Therefore, in order to achieve optimal harmonisation of interests of conservation and protection of national water resources and development interests of the Croatian economy, it is particularly necessary to take into account the multiplicative effects of cross-sectoral dependencies on water use when conducting activities of planning, management, and protection of Croatian water resources.

\section{Conclusions}

In order to comprehensively understand the impact of cross-sectoral dependencies on the total economic use of water in the Republic of Croatia, the water extended input-output model of the Croatian economy has been developed in this paper. Based on this model, three levels of input-output analysis were conducted. The indicators of direct, indirect, and cumulative water intensity of production sectors in the Croatian economy, including multipliers of their water use, were calculated and analysed first. Subsequently, domestic, net imported, and total water footprints of the Croatian economy and its production sectors were also calculated and analysed. Finally, the pull and push effects of final demand on economic water use flows in the Republic of Croatia were calculated and analysed as well. According to the results of the analysis, it can be concluded that the Croatian economy has a highly homogeneous structure of direct water use, which is mostly concentrated in several basic industrial sectors. Since a significant part of the output of these sectors is integrated into value chains of national production, the production activities of other sectors have a significant multiplicative impact on the flows of direct and indirect water use in the Croatian economy. Consequently, it can be concluded that the level of total economic water use in the Republic of Croatia is dominantly conditioned by intermediate processes of production and consumption 
of outputs of the power, chemical, and oil-processing sector. Also, the analysis of water footprint indicators showed that the Republic of Croatia achieves a surplus in the international exchange of virtual waters, which in view of the relatively high abundance of water resources in the territory of the Republic of Croatia indicates the underdevelopment and structural non-adjustment of water-intensive production capacities of the Croatian economy in relation to the intermediate demand of domestic producers.

Considering the guidelines for future input-output research of the impact of the Croatian economy on water resources, the model presented in this paper can also be used for quantification and analysis of direct, indirect, and cumulative wastewater flows in the Croatian economy, as well as for assessment of the corresponding sectoral wastewater footprints. However, due to the existence of regional disparities in the availability of water resources in the territory of the Republic of Croatia, but also due to inequalities in structural characteristics and the development of regional economies, it is not possible to determine, based on this model, how the flows of the production and consumption of goods and services within and between Croatian regions affect national water resources. Therefore, one of the future research challenges should be related to the construction and empirical application of a multi-regional hybrid input-output model of water use and water pollution in the Croatian economy.

\section{References}

Alonso, E. V. (2004) "Impact Analysis and Extraction Method: Applications on water resources in Andalusia", Regional Economic Applied Laboratory, Urbana: University of Illinois. Available at: $<$ https://www.iioa.org/conferences/ intermediate-2004/pdf/426.pdf $>$.

Aquastat database. Food and Agriculture Organization of the United Nations. Available at: $<$ http://www.fao.org/nr/water/aquastat/data/query/> .

Bekchanov, M. et al. (2014) "Integrating input-output modeling with multi-criteria analysis to assess options for sustainable economic transformation: the case of Uzbekistan", In The Global Water System in the Anthropocene, Cham: Springer Water, pp. 229-245.

Biondić, D. ed. (2009) National Water Management Strategy, Zagreb: Hrvatske vode.

CBS (2015) Input-output table for 2010, Zagreb: CBS. Available at: <https://www. dzs.hr/Hrv_Eng/publication/2015/12-01-04_01_2015.xlsx>.

CBS (2015) Utilisation of waters and protection of waters from pollution in industry, 2011, Zagreb: CBS. Available at: <https://www.dzs.hr/Hrv_Eng/ publication/2012/06-01-01_01_2012.htm>. 
Davar, E. (2005) "Input-Output System Models: Leontief versus Ghosh", in 15th International Input-Output Conference, June 27 - July 1, Beijing. Available at: $<$ https://www.iioa.org/conferences/15th/pdf/ezra_davar.pdf $>$.

Di Cosmo, V., Hyland, M. \& Llop, M., (2014) "Disentangling water usage in the European Union: A decomposition analysis", Water resources management, Vol. 28, No. 5, pp.1463-1479.

Duarte, R. \& Sánchez-Chóliz, J. (1998) "Regional Productive Structure and Water Pollution: An Analysis using the Input-Output Model", In 38th Congress of The European Regional Science Association, August 28 - September 1, Vienna: European Regional Science Association. Available at: <https://www.econstor. eu/bitstream/10419/113438/1/ERSA1998_110.pdf $>$.

Duarte, R. \& Yang, h. (2011) "Input-output and water: introduction to the special issue", Economic Systems Research, Vol. 23, No. 4, pp. 341-351.

Eunnyeong, H., Junyoung, P. \& Tai-Yoo, K. (1999) "Input-output analysis on the Korean water supply industry", in Water Resources Planning and Management: Proceedings of the International Conference on Water, Environment, Ecology, Socio-economics and Health Engineering, October 18-21, Seoul, Seoul National University, pp. 106-112.

Eurostat (2008) Eurostat Manual of Supply, Use and Input-Output Tables, Luxembourg: Office for Official Publications of the European Communities.

Frenger, P. (1978) "Factor substitution in the interindustry model and the use of inconsistent aggregation, in Production economics: Approach to theory and applications", Amsterdam: North-Holland Publishing Company, pp. 269-310. Available at: $<$ https://eml.berkeley.edu/ mcfadden/prodecon/apps/ch17.pdf $>$.

Gerking, S.D. (1976) Estimation of stochastic input-output models: some statistical problems, Studies in Applied Regional Science, Vol. 3, Springer.

Gretton, P. (2013) On input-output tables: uses and abuses, Staff Research Note, Canberra: Productivity Commission.

Giljum, S. et al. (2013) State-of-play of national consumption-based indicators: a review and evaluation of available methods and data to calculate footprint-type (consumption-based) indicators for materials, water, land and carbon, Vienna: Sustainable Europe Research Institute.

Guan, D. \& Hubacek, K. (2006) "Assessment of regional trade and virtual water flows in China", Ecological economics, Vol. 61, No. 1, pp. 159-170.

Gupta, K.R. (2009): Economics of development and planning, New Delhi: Atlantic Publishers \& Dist.

Hermannsson, K. et al. (2010) "An HEI-disaggregated input-output table for Scotland", Glasgow: Department of Economics, University of Strathclyde.

Hoekstra, A.Y. et al. (2011) The Water Footprint Assessment Manual - Setting the Global Standard, London: Earthscan Ltd, Washington, DC: Earthscan LLC. 
Hoekstra, A.Y. \& Chapagain, A. K. (2008) Globalization of Water: Sharing the Planet's Freshwater Resources, Oxford: Blackwell Publishing.

Hoekstra, A.Y. \& Hung, P.Q. (2002) A Quantification of Virtual Water Flows Between Nations in Relation to International Crop Trade, Value of Water Research Report Series 11, Delft: IHE Delft.

Hristov, J., et al. (2012) "Input-Output analysis for water consumption in Macedonia", in European Summer School in Resource and Environmental Economics Management of International Water, July 1-7, Venice, Italy, pp. 1-33.

Jain, T. R. \& Ohri, V. K., et al. (2007) Development Economics, New Delhi: VK Publications.

Jian, F. H., Song, X. Y. \& Li, L. L. (2016) "The evolution and enlightenment of water resources accounting from accounts to balance sheet", Sciences in Cold and Arid Regions, Vol. 8, No 2, pp. 156-162.

Jurčić, L. (2000) "Development of input-output analysis in Croatia", Ekonomski pregled, Vol. 51, No. 11-12, pp. 1313-1333.

Kobayashi, Y., \& Oyasato, N. (2008) "An estimation of embodied intensity of water consumption in Japan based on input-output analysis method", Journal of Life Cycle Assessment, Vol. 4, No. 4, pp. 359-366.

Kurz, H. D. \& Salvadori, N. (2000) "'Classical' Roots of Input-Output Analysis: A Short Account of its Long Prehistory", Economic Systems Research, Vol. 12, No. 2, pp. 153-79.

Lenzen, M. \& Foran, B. (2001) "An input-output analysis of Australian water usage, Water Policy”, Vol. 3, No. 4, pp. 321-340.

Leontief, W. (1986) Input-output economics, New York: Oxford University Press, $2^{\text {nd }}$ edition.

Maresa, A. \& Sancho, F. (2012) "Leontief versus Ghosh: two faces of the same coin", Working Papers XREAP 2012-18, Xarxa de Referéncia en Economia Aplicada. Available at: <http://www.ub.edu/ubeconomics/wp-content/uploads/ 2013/01/XREAP2012-18.pdf $>$.

Mikulić, D. et al. (2014) Metodološki priručnik za procjenu učinaka propisa na određene makroekonomske varijable, Zagreb: Institute of Economics.

Mikulić, D. (2018) Osnove input-output analize s primjenom na Hrvatsko Gospodarstvo, Ekonomski institut, Zagreb: Institute of Economics.

Miller, R. E. \& Blair, P. D. (2009) Input-Output analysis - Foundations and Extensions, Cambridge: Cambridge University Press.

NWT Bureau of Statistics (2006): "NWT Input-Output Model - An Overview", Yellowknife NT: NWT Bureau of Statistics, Available at: <http://www.statsnwt. ca/economy/multipliers/NWT\%20IO\%20Model-Overview.pdf>.

OECD (1992) Structural change and industrial performance: a seven country growth decomposition study, Paris: OECD. 
Qin, C. (2011) Mitigating China's water scarcity and pollution: environmental and economic accounting, modelling and policy analysis, University of Twente, Faculty of Geo-Information Science and Earth Observation. Available at: $<$ https://webapps.itc.utwente.n1/librarywww/papers_2011/phd/qin.pdf $>$.

Rasmussen, P. (1956) Studies in intersectoral relation, Amsterdam: North Holland.

Renault, D. (2003) "Value of virtual water in food: principles and virtues", In Virtual water trade Proceedings of the International Expert Meeting on Virtual Water Trade, Value of Water Research Report Series No. 12, Delft: IHE Delft, pp. 77-91.

Sun, Y. Y. \& Wong, K. F. (2014) "Stability of input-output coefficients by capacity utilization for short-term tourism demand fluctuation", Tourism Economics, Vol. 20, No. 3, pp. 509-526.

Ten Raa, T. (2006) The economics of input-output analysis, Cambridge: Cambridge University Press.

Tukker, A. et al. (2006) Environmentally extended input-output tables and models for Europe, Joint Research Centre, Institute for Prospective Technological Studies.

Velazquez, E. (2006) "An input-output model of water use: analysing intersectoral water relationships in Andalusia”, Ecological Economics, Vol. 56, No. 2, pp. 226-240.

Voća et al. (eds.) (2014) Izvješće o stanju okoliša u Republici Hrvatskoj, 2014. (razdoblje od 2009. do 2012.), Zagreb: Croatian Agency for the Environment and Nature. Available at: <http://www.haop.hr/sites/default/files/uploads/ dokumenti/06_integrirane/dokumenti/niso/Izvjesce $\% 200 \% 20$ stanju $\% 20$ okolisa\%20u\%20RH_\%202009-2012.pdf>.

Yakovleva, E. \& Kudryavtseva, O. (2013) "The Application of Intersectoral InputOutput Model for Water Consumption and Air Pollution in Russia". Available at: $<$ https://dx.doi.org/10.2139/ssrn.2260915>.

Yu, Y. et al. (2010) "Assessing regional and global water footprints for the UK", Ecological Economics, Vol. 69, No. 5, pp. 1140-1147. 


\title{
Vodom proširena input-output analiza hrvatskog gospodarstva ${ }^{1}$
}

\author{
Saša Čegar ${ }^{2}$
}

\begin{abstract}
Sažetak
Osnovni cilj ovog rada je identificirati najznačajnije izravne $i$ neizravne izvore potrošnje vode u hrvatskom gospodarstvu te na osnovu toga ukazati na ključne pokretače potrošnje vode u procesu hrvatske nacionalne proizvodnje. U svrhu toga, u radu je konstruiran i empirijski primijenjen vodom prošireni input-output model na temelju kojeg su kvantificirani i analizirani pokazatelji izravne, neizravne $i$ kumulativne vodne intenzivnosti proizvodnih sektora u hrvatskom gospodarstvu, uključujući njihove kumulativne i neizravne multiplikatore potrošnje vode. Pomoću spomenutog modela u radu su također procijenjeni $i$ analizirani domaći, neto uvezeni i ukupni vodeni otisci proizvodnih sektora u hrvatskom gospodarstvu, kao $i$ relativna snaga pull $i$ push efekata njihove potrošnje vode. Za potrebe konstrukcije modela korištena je posljednje objavljena input-output tablica hrvatskog gospodarstva za 2010. godinu te referentni podaci hrvatske službene vodne statistike. Rezultati modela ukazuju da su izravni $i$ neizravni tokovi potrošnje vode $u$ hrvatskom gospodarstvu najvećim dijelom determinirani intermedijarnim procesima stvaranja i raspodjele outputa elektro-energetskog, kemijskog i naftno-prerađivačkog sektora. Također, modelom je utvrđeno da ovi sektori dominiraju u strukturi ukupnog vodenog otiska hrvatskog gospodarstva, pri čemu Republika Hrvatska, ukupno gledajući, ostvaruje suficit u međunarodnoj razmjeni virtualnih voda. S obzirom na novo dobivene spoznaje o neizravnim $i$ kumulativnim tokovima potrošnje vode u hrvatskom gospodarstvu, preporuka je autora da se prilikom provođenja budućih aktivnosti planiranja, upravljanja $i$ zaštite hrvatskih vodnih resursa moraju uzeti u obzir i multiplikativni učinci međusektorskih zavisnosti u procesima nacionalne proizvodnje na ukupnu potrošnju vode.
\end{abstract}

Key words: hrvatsko gospodarstvo, proširena input-output analiza, neizravna intenzivnost vode, kumulativna intenzivnost vode, vodeni otisci, veze prema unaprijed i prema unazad

JEL klasifikacija: C67, E01, E10, F18, Q25

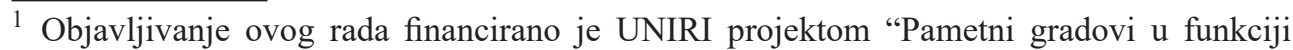
razvoja nacionalnog gospodarstva" (uniri-drustv-18-255-1424).

2 Docent, Sveučilište u Rijeci, Ekonomski fakultet, Ivana Filipovića 4, 51000, Rijeka, Hrvatska. Znanstveni interes: ekonomika i politika okoliša, urbana ekonomika, lokalni i regionalni razvoj.Tel.: +385 51355 120. E-mail: sasa.cegar@efri.hr.ORCID:0000-0001-8666-3419. 


\section{Appendices}

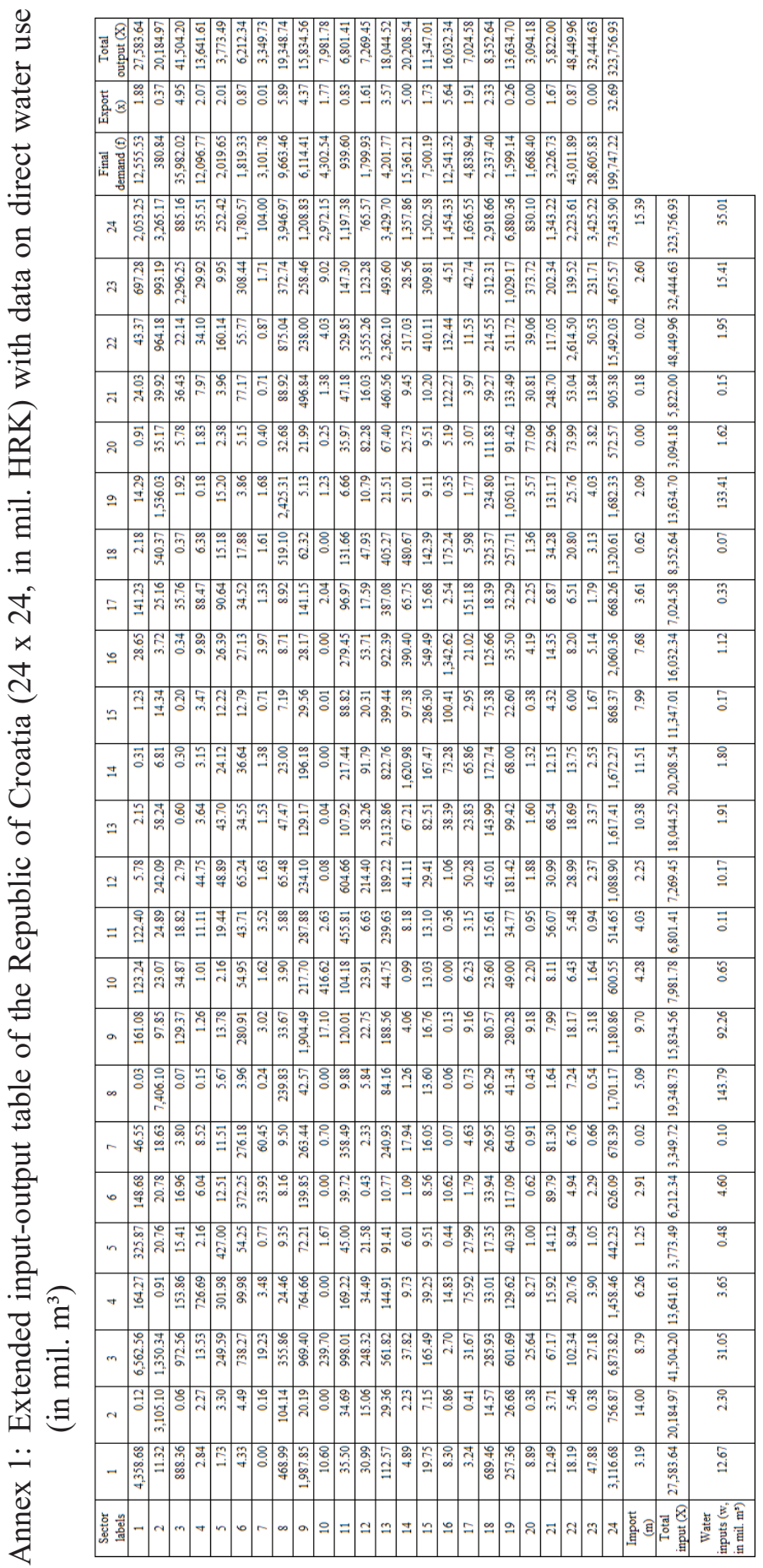




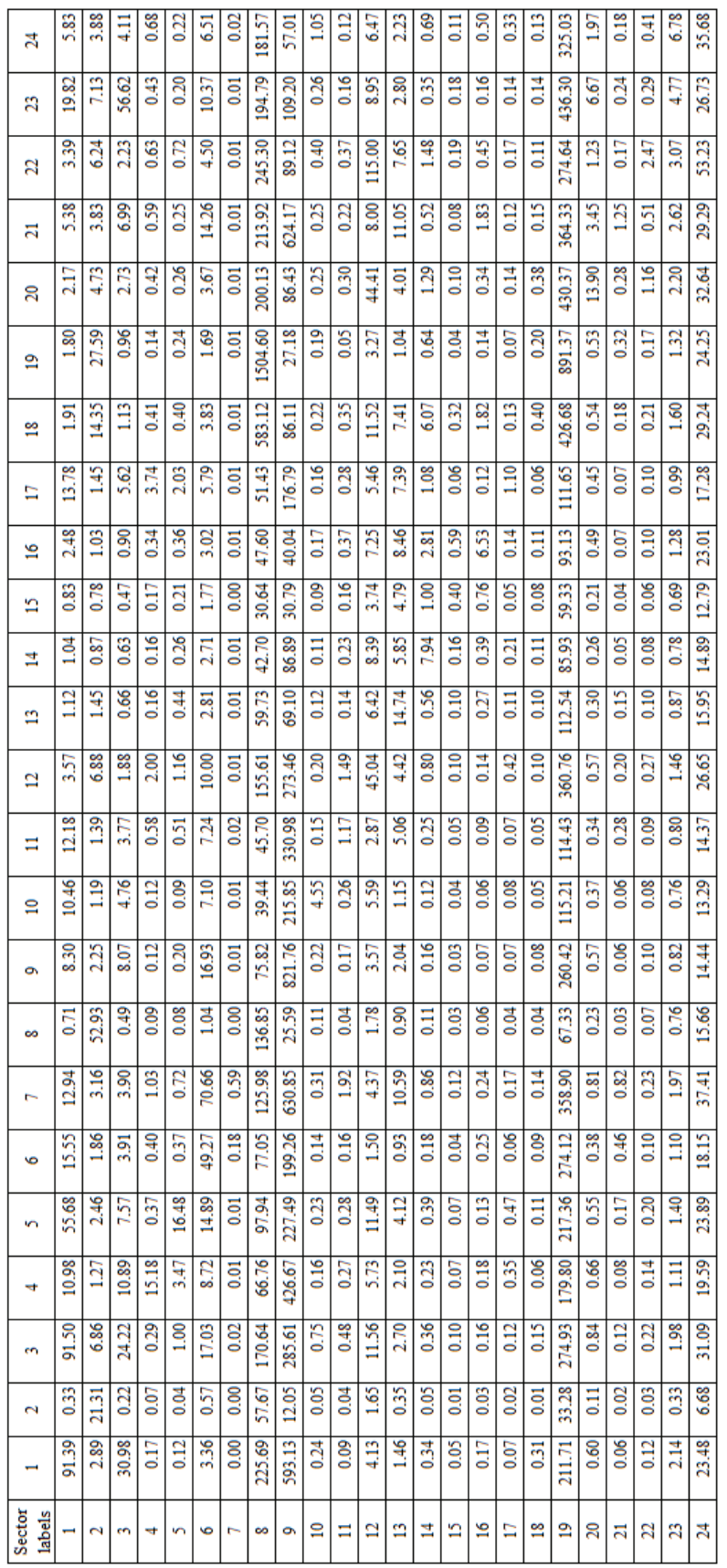


Annex 3: Matrix of technical coefficients of cumulative water use (Q)

\begin{tabular}{|c|c|c|c|c|c|c|c|c|c|c|c|c|c|c|c|c|c|c|c|c|c|c|c|c|}
\hline $\begin{array}{l}\text { Sector } \\
\text { labels }\end{array}$ & 1 & 2 & 3 & 4 & 5 & 6 & 7 & 8 & 9 & 10 & 11 & 12 & 13 & 14 & 15 & 16 & 17 & 18 & 19 & 20 & 21 & 22 & 23 & 24 \\
\hline 1 & & & & .04 & 0.43 & & 0.42 & 0.00 & 0.00 & & & & .01 & 0.01 & 0.06 & & & & & & & .08 & 0.04 & 0.05 \\
\hline 2 & 101 & 10 & & 00 & 00 & 0 & 10 & .01 & 0.00 & & 0.09 & & .01 & 0.01 & 0.05 & & & 64 & 00 & ] & .14 & .16 & 0.02 & 0.04 \\
\hline 3 & 07 & .00 & & .04 & 0.06 & 001 & 0.13 & 0.00 & 0.00 & & 0.24 & .00 & .01 & 0.01 & 0.03 & 01 & 12 & 13 & .00 & ] & .26 & .06 & 0.12 & 0.04 \\
\hline 4 & .00 & 0.00 & .00 & .06 & 0.00 & 0.00 & 0.03 & 0.00 & 0.00 & 0 & 0.04 & .00 & 0.00 & 0.00 & 0.01 & & & 05 & .00 & & .02 & .02 & 0.00 & 0.01 \\
\hline 5 & 00 & .00 & .00 & .01 & 0.13 & $0.0 \mathrm{C}$ & 0.02 & 0.00 & 0.00 & 0 & 0.03 & 0.00 & 0.00 & 0.00 & 0.01 & 01 & 204 & 0.05 & .00 & 08 & .01 & .02 & 0.00 & 0.00 \\
\hline 6 & 01 & .00 & & 0.03 & 0.12 & 0.07 & 30 & 0.00 & 0.00 & 0 & 0.46 & 0.01 & 0.03 & 0.03 & 0.12 & 0.04 & & 44 & 0.00 & & 0.54 & .11 & 0.02 & 0.06 \\
\hline 7 & 00 & 00 & & 00 & 00 & & & 0.00 & & & & 00 & .00 & & 00 & 00 & & 00 & 0.00 & & 00 & 0.00 & 0.00 & 0.00 \\
\hline 8 & 49 & .51 & 23 & 25 & 0.76 & 0.10 & 10 & 0.02 & 0.01 & 0.49 & 90 & 0.11 & 0.56 & 0.48 & 2.09 & 0.68 & 1.09 & 6.72 & 0.15 & 0.3 & 3.09 & 6.10 & 0.41 & 1.68 \\
\hline 9 & 29 & .11 & 38 & 60 & 1.77 & 0.27 & .52 & 0.00 & 0.14 & 2.67 & 1.04 & 0.20 & 0.65 & 0.98 & 2.10 & 0.57 & 3.74 & 85 & 0.00 & 0.16 & 23.60 & 2.22 & 0.23 & 0.53 \\
\hline 10 & 00 & .00 & 00 & .00 & 0.00 & 0.00 & 01 & 0.00 & 0.00 & 0.0 & & 0.00 & 0.00 & 0.00 & 0.01 & 0.00 & 0.0 & & 0.00 & 0. & 0.01 & 0.01 & 0.00 & 0.01 \\
\hline 11 & 00 & .00 & 00 & 0.00 & 0.00 & 0.00 & .06 & 0.00 & 0.00 & 0.0 & 0.07 & 0.00 & 0.00 & 0.00 & 0.01 & 0.01 & 0.01 & 04 & 0.0 & 0. & 0.01 & 0.01 & 0.00 & 0.00 \\
\hline 12 & 01 & .01 & 02 & 0.02 & 0.09 & 0.00 & 14 & 0.00 & 0.00 & 0.0 & & 0.03 & 0.06 & 0.09 & 0.26 & 0.10 & 0.12 & & 0.0 & 08 & .30 & 2.86 & 0.02 & 0.06 \\
\hline 13 & 0.00 & .00 & 0.00 & 0.01 & 0.03 & 0.00 & 0.34 & 0.00 & 0.00 & 0.01 & 0.32 & 0.00 & 0.14 & 0.07 & 0.33 & 0.12 & 0.16 & 0.85 & 0.00 & 0.01 & 0.42 & 0.19 & 0.01 & 0.02 \\
\hline 14 & .00 & .00 & 0.00 & 0.00 & 0.00 & 0.00 & 0.03 & 0.00 & 0.00 & 0.00 & 0.02 & 0.00 & 0.01 & 0.09 & 0.07 & 0.04 & 0.02 & .70 & 0.00 & 0.00 & 02 & 0.04 & 0.00 & 0.01 \\
\hline 15 & 00 & .00 & 0.00 & 0.00 & 0.00 & 0.00 & 0.00 & 0.00 & 0.00 & 0 & 0.0 & 0.00 & 0.00 & 0.00 & 0.03 & 0.01 & 0.00 & 04 & 0.00 & 0.00 & .00 & 0.00 & 0.00 & 0.00 \\
\hline 16 & 00 & .00 & 00 & .00 & 0.00 & 0.00 & .01 & 0.00 & 0.00 & 0 & & 00 & 0.00 & 0.00 & .05 & .09 & 0.0 & 21 & 0.0 & & 07 & 0.01 & 0.00 & 0.00 \\
\hline & 00 & .00 & & 00 & .00 & & & 0.00 & & & & & .00 & & 00 & .00 & & 01 & & & 00 & 0.00 & .00 & 0.00 \\
\hline & 00 & .00 & 0.00 & 0 & 0.00 & 0.00 & & 0.00 & 0.00 & & & & 0.00 & 0.00 & 0.01 & & & & 0.00 & 0.00 & .01 & 0.00 & 0.00 & 0.00 \\
\hline & .46 & .29 & 0.37 & 0.67 & 1.69 & 0.37 & 11.67 & 0.01 & 0.04 & 1.43 & 7.27 & 0.26 & 1.06 & 0.97 & 4.06 & 1.33 & 2.36 & 48.82 & 0.09 & 0.82 & 13.77 & 6.83 & 0.92 & 3.01 \\
\hline 20 & 0.00 & 0.00 & 0.00 & 0.00 & 0.00 & 0.00 & 0.03 & 0.00 & 0.00 & 0.00 & 0.02 & 0.00 & 0.00 & 0.00 & 0.01 & 0.01 & 0.01 & 0.00 & 0.00 & 0.03 & 0.15 & 0.03 & 0.01 & 0.02 \\
\hline 21 & 0.00 & 0.00 & 0.00 & 0.00 & 0.00 & 0.00 & 0.03 & 0.00 & 0.00 & 0.00 & 0.02 & 0.00 & 0.00 & 0.00 & 0.00 & 0.00 & 0.00 & 0.02 & 0.00 & 0.00 & 0.05 & 0.00 & 0.00 & 0.00 \\
\hline 22 & 0.00 & 0.00 & 0.00 & 0.00 & 0.00 & 0.00 & 0.01 & 0.00 & 0.00 & 0.00 & 0.01 & 0.00 & 0.00 & 0.00 & 0.00 & 0.00 & 0.00 & 0.02 & 0.00 & 0.00 & 0.02 & 0.06 & 0.00 & 0.00 \\
\hline 23 & 0.00 & 0.00 & 0.00 & 0.00 & 0.01 & 0.00 & & 0.00 & 0.00 & 0.0 & 0.05 & 0.00 & 0.01 & 0.01 & 0.05 & 0.02 & 0.02 & & 0.00 & 0.00 & 0.10 & 0.08 & 0.01 & 0.06 \\
\hline 24 & 0.05 & 0.06 & 0.04 & 0.07 & 0.19 & 0.02 & 1.22 & 0.00 & 0.00 & 0.16 & 0.91 & 0.02 & 0.15 & 0.17 & 0.87 & 0.33 & 0.37 & 3.3. & 0.00 & 0.00 & 1.11 & 1.32 & 0.06 & 0.33 \\
\hline
\end{tabular}

Source: Author's calculation 